\title{
Erzincan Ovası ve Dolayının Çevre Jeolojisi ve Planlanmasına Bir Yaklaşım
}

An Approach to the Planning and Environmental Geology of Erzilncan Plain and its

\author{
Surroundings \\ Doğuş BOZ ${ }^{1} \mathbb{D}$, Ali YILMAZ ${ }^{\mathbb{D}}$ \\ ${ }^{1}$ Cumhuriyet Üniversitesi, Fen Bilimleri Enstitüsü, 58140, Sivas \\ ${ }^{2}$ Ümit Mah. Çamlıca Vadi Sitesi, A/17, Çankaya-Ankara
}

Geliş (Received): 19 Kasım (November) 2019 / Düzeltme (Revised): 06 Şubat (February) 2020 / Kabul (Accepted): 03 Nisan (April) 2020

\section{ÖZ}

Erzincan ovası, Doğu Anadolu Bölgesi'nin Yukarı Fırat havzasında, deprem, heyelan, çığ, sel ve taşkın gibi doğa kaynaklı risklerin tehdidi altında olan bir yörede yer almaktadır. Erzincan, tarihi boyunca çeşitli büyüklüklerde depremlere sahne olmuştur. 1939 ve 1992 yıllarında oluşan depremler, insanlar ve yapılar üzerinde önemli derecede can ve mal kayıplarına neden olmuştur. Sunulan çalışmada Erzincan Ovası ve yakın dolayının bölgesel ve yerel jeolojisi ışı̆̆ında jeomorfolojisi, hidrojeolojisi, doğal kaynakları, arazi yetenek değerlendirmesi, günümüzdeki arazi kullanımı gözetilerek çevre jeolojisi ortaya koyulmuş ve buna bağlı olarak geleceğe yönelik arazi kullanım planlaması değerlendirilmiştir. Çalışmanın ana konusunu oluşturan çevre jeolojisi çerçevesinde yörenin çevresel sistemleri tanımlanmıştır. Bu sistemler başlıca Erzincan Ova Sistemi, Ergan Dağı Sistemi, insan faaliyetleri sonucu değişime uğramış sistem olup, ayrıca her sistemi karakterize eden çevresel birimler ayırt edilmiştir. Böylece 26 çevresel birim, genel ve indeks özellikler ile doğa kaynaklı riskler açısından tanımlanarak, bu birimlerin arazi yetenek değerlendirmesi yapılmıştır. Arazi yetenek değerlendirmesi, arazi kullanım biçimleri gözetilerek gerçekleştirilmiştir. Ayrıca Erzincan Ovası'nın ve yakın dolayının Çevre Jeolojisi ışığında, doğa kaynaklı risklerin egemen olduğu bu bölgenin, geleceğe yönelik planlamasında gözetilmesi gereken hususlar ortaya koyulmuştur. Günümüzdeki arazi kullanım biçimleri gözden geçirildiğinde yörede yeni bir planlamaya gereksinim olduğu anlaşılmaktadır. Öngörülen planlama esas alınırsa, çevresel sorunların büyük bir bölümünün denetlenip, Erzincan Ovası ve dolayının korunması da mümkündür.

Anahtar kelimeler: Çevre Birimleri, Çevre Jeolojisi, Çevresel Sistemler, Erzincan Ovası, Arazi Kullanım Planı

\begin{abstract}
Erzincan plain is located in an area, where earthquakes, landslides, avalanches, floods and other natural disasters are mainly dominant in the upper part of Firat River basin in the East Anatolian Region. Earthquakes of various magnitudes occurred throughout the history of Erzincan. Earthquakes occurred in the 1939 and 1992 years led to many casualties and lost of the properties. In the present study, in the light of regional and local geology of the Erzincan Plain and vicinity considering - its geomorphology, hydrogeology, natural resources, land-use capability, currentland-use and its environmentel geology have been presented and related future land use planning have been evaluated. Environmental systems have been defined in the frame of environmental geology. These systems are mainly Erzincan Plain System, Erganda $\breve{g}$ System and Man-made or Antropogenic System. Environmental units those characterize each system have been identified. Thus, land-use capabilities of 26 environmental units have been
\end{abstract}


Boz, Yılmaz

evaluated depending on their general properties, index characteristics and natural disaster risks. The evaluations of land-use capabilities have been carried out on the basis of land-use forms. The matters, which are necessary to be considered to wards to the planning of the region in the future, have been presented. Based on the recommended plan, it is possible to control a great deal of environmental problems and protect the Erzincan Plain and surroundings, as well.

Keywords: Environmental Geology, Erzincan Plain, Environmental Systems, Environmental Units, Land Use Planing.

\section{GIiRIŞ}

Erzincan Ovas1, Doğu Anadolu'nun batısında, Sivas'tan Kars'a doğru uzanan demiryolu ile Sivas-Erzurum ve TrabzonMalatya karayollarının birbirine kavuştuğu bir kavşakta; Türkiye'nin doğu kesiminde yer almaktadır (Şekil 1).

Erzincan Ovası ve yakın dolayı, jeolojik açıdan çeşitli çalışmalara sahne olmuştur (Özgül, 1981; Yılmaz, 1985; MTA, 2003). Bölgenin tektonik (Arpat ve Şaroğlu, 1975; Barka, 1984; Koçyiğit, 1991; Emre vd. 2012), petrolojik (Aktimur vd., 1995), hidrojeolojik (DSİ, 1981), jeomorfolojik (Keçer, 1985), arazi kullanım (Aktimur vd., 1988) ve mevcut çevresel durumu (Erzincan Valiliği, 2011) incelenmiştir. Yukarıda sunulan çalışmalar irdelenerek bölgenin çevre jeolojisi de değerlendirilmiştir (Boz, 2015). Dolayısıyla, söz konusu bölge çeşitli açılardan iyi bilinmektedir.

Çevre jeolojisi haritalamasında ise, önce yere özgü coğrafya, morfoloji, doğal görünüm ve mevcut arazi kullanımları ışı̆̆ında çevresel sistemler tanımlanır. Herhangi bir alan için pek çok sayıda çevresel sistem tanımlanabilir. Daha sonra da her sistem, benzer jeolojik özellikler, bitki örtüsü, toprak kalınlığ ve arazi kullanım biçimleri gibi özellikler de gözetilerek çevresel birimlere ayrlmaktadır (Brown vd., 1971;
Turner ve Coffman, 1973; Cendero, 1974; Yılmaz, 2008). Mühendislik jeolojisi haritaları (Shrestha vd., 1999; Tudes vd., 2012), tekil proje özelinde ve projenin çevresel etkileri konusunda sağlıklı bilgi verir ve çevrenin korunmasına katkı sağlar. Çevre jeolojisi haritaları ise giderek gelişmektedir (Doornkamp vd., 1987; Mulder ve Hillen, 1990; Faccini vd., 2008). Bu haritalar, temel jeolojik haritalardan elde edilen verilerin diğer çevresel (doğal ve insan yapısı) verilerle kombinasyonu sağlayan ve çevrenin mevcut durumu ile geleceğe yönelik planlanmasını birlikte değerlendirmeye ve geliştirmeye açık haritalardır.

Söz konusu çaba, özellikle Stratejik Çevresel Etki Değerlendirmesi uygulamalarında, öngörülen plan ve programların bölgesel düzeyde kümülatif etkilerini de değerlendirmeyi kolaylaştırmaktadır. Ayrıca bu haritalarda, her çevresel birim deprem, heyelan, sel ve taşkın, aşınma (erozyon), yağış, toprak oluşumu ve doğal yaşamın verimliliği gibi doğa kaynaklı yer süreçleri yönüyle ve konuya özel hazırlanabilen matrislerle birlikte değerlendirilebilir. Dolayısıyla çevre jeolojisi haritalarının bölgesel düzeyde çevrenin korunmasına katkısı vardır. Bu katkı da çevrenin geleceği ve sürdürülebilirliği açısından önemlidir. 


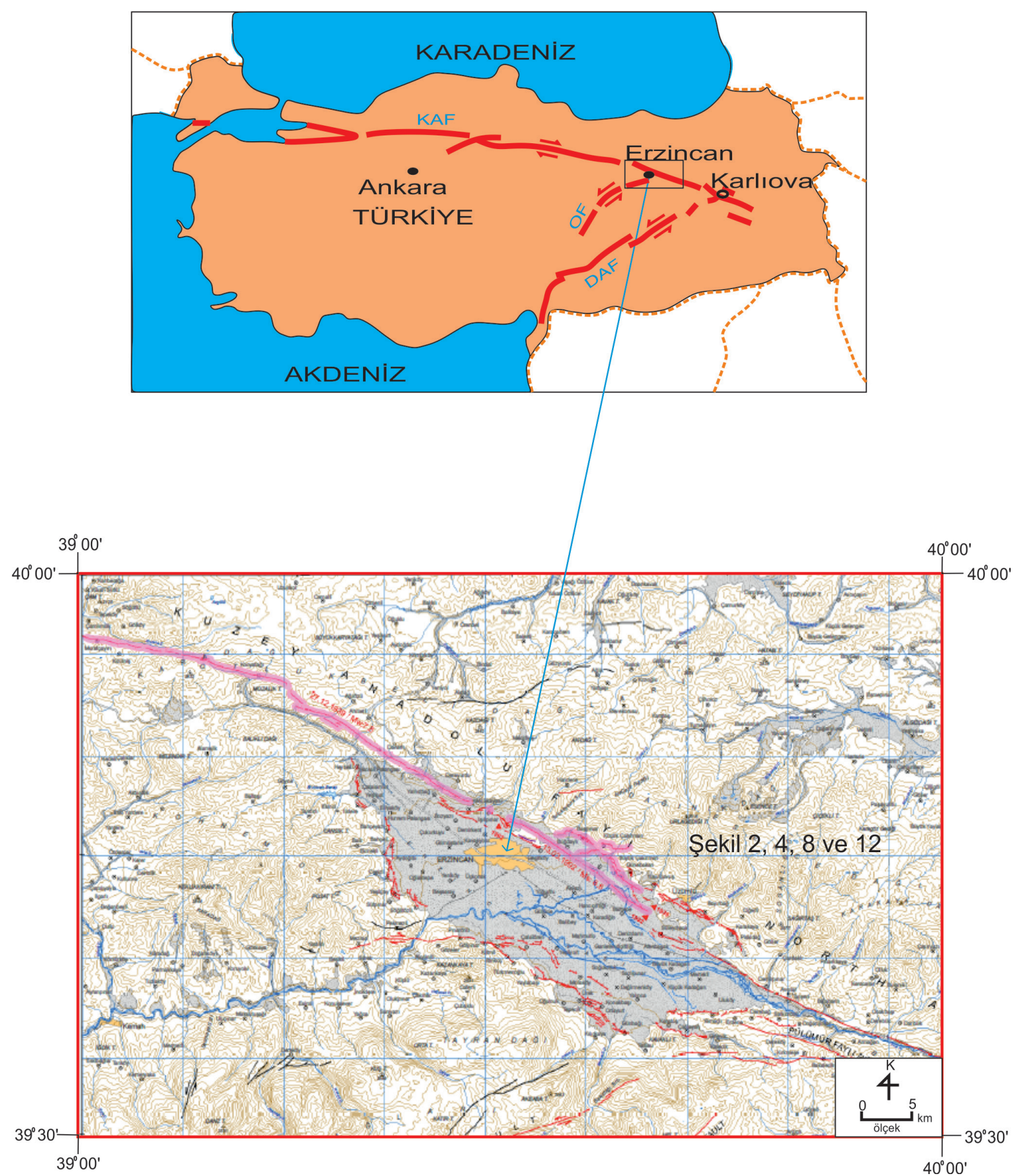

Şekil 1. Erzincan Ovası ve dolayının bulduru haritası (MTA, 2012a). KAF, Kuzey Anadolu Fay Zonu; DAF, Doğu Anadolu Fay Zonu; OF, Ovacik Fay Zonu.

Figure 1. Location map of the Erzincan Plain and surroundings (MTA, 2012a). KAF, North Anatolian Fault; DAF, East Anatolian Fault; OF, Ovacık Fault. 
Sunulan çalışmanın en önemli amacı, yöreye dair jeolojik, jeomorfolojik, hidrojeolojik, doğal kaynaklar ve arazi kullanım potansiyeli 1şığında; yörenin çevre jeolojisini ortaya koymak ve bölgenin geleceğe yönelik arazi kullanım planlamasına katkı sağlamaktır. Bu çerçevede, Erzincan Ovası ve yakın dolayının morfolojisi ve arazi kullanımı gözetilerek çevresel sistemler tanımlanmıştır. Daha sonra tanımlanan her bir sistem için kaya türleri gözetilerek çevresel birimler tanımlanmıştır. Ayrıca çevresel sistemlerle birlikte çevresel birimlerin arazi yetenek sinıflaması gözetilerek ortaya koyulan bilgilerle mevcut bölgesel planlama değerlendirilmiş ve geleceğe yönelik arazi planlamasının daha doğru bir yönde yapılmasına katkıda bulunulmuştur.

Önemli doğa kaynaklı risklerin tehdidi altındaki bir bölgede geleceğe yönelik bir planlama yapmak güçtür. Bunun için öncelikle mevcut durumu ortaya koymak üzere bölgenin çevre jeolojisi haritasını oluşturmak gerekmektedir. Sunulan bu makaledeki çevre jeolojisi çalışması daha önce yapılan çevre jeolojisi çalışmalarından (Cendero, 1974; Faccini vd., 2008) esinlenerek yapılmıştır. Böylece yörenin geniş çerçevede bölgesel açıdan durumunu belirlemek mümkündür. Sonuç olarak, sunulan çalışmada, ilk kez hazırlanan Erzincan Ovası'nın çevre jeolojisi haritası gözetilerek, bölgenin planlanmasına dair bir yaklaşımda bulunulmuştur.

Çevre jeolojisi haritalamasının başka bir amacı, planlamacılara en geniş çerçevede yol göstermektir. Bunun için, jeolojik bilgi ile kayaların ya da zeminlerin hidrojeolojik ve mühendislik özellikleri kolaylıkla anlaşılabilecek bir biçimde sunulmalıdır. Çevre jeolojisi haritaları planlamanın türü için gerekli önemli bilgileri içermeli ve konu dışı verileri de özenle ayıklamalıdır. Uygulama yönüyle en iyi çevre jeolojisi haritaları, jeolojik, hidrojeolojik ve jeoteknik-mühendislik özelliklerini çevrenin diğer nitelikleri ile birlikte sunan haritalardır. Bir bölgenin çevre jeolojisi haritalaması, mevcut arazi kullanım biçimleri gözetilerek hazırlanabileceği gibi, olası yeni arazi kullanım biçimlerini de gözeten bileşik bir yapıda da hazırlanabilir.

\section{ERZINCAN OVASI VE DOLAYININ MEVCUT ÇEVRESEL ÖZELLİKLERİ}

$\mathrm{Bu}$ bölümde bölgenin mevcut durumunu tanımlamak üzere sıra ile jeolojik, hidrojeolojik, jeomorfolojik özelliklere, doğal kaynaklara ve arazi kullanımına dair temel bilgiler sunulmuştur. Daha sonra, yörenin çevre jeolojisinin yanı sıra arazi yetenek değerlendirmesi yapılmış ve geleceğe yönelik planlaması yeniden gözden geçirilmiştir.

\section{Erzincan Ovası ve Yakın Dolayının Jeolojisi}

Öncelikle bölgesel jeolojiyi ve buna bağl1 yerel jeolojiyi ayrı ayrı irdelemekte yarar vardır. Genel ayrıntılardan özel ayrıntılara yönelmek kimi zaman bazı kolaylıklar sağlamaktadır.

\section{Bölgesel jeoloji}

Erzincan yöresinde bölgesel düzeyde, farkl1 ortam koşullarını yansıtan ve birbiri ile tektonik ilişkili, Eosen öncesi yaşta olan dört temel tektono-stratigrafik birim ayırtlanmıştır. Bunlar kuzeyden güneye doğru Kelkit Göreli otoktonu, Çimen Dağı Nap1, Erzincan Nap1 ve Munzur Kireçtaşı'dır. Bu naplardan Çimen Dağı Nap1, kuzeydeki Kelkit Otoktonu'nun ve güneydeki Erzincan Napı'nın üzerinde, Erzincan Napı ise 
Çimendağı Napı'nın'nın altında ve Munzur Kireçtaşı'nın üzerinde yer almaktadır (Yılmaz, 1985).

İnceleme alanında ise Doğu Pontidler'in güney kenarını temsil eden Çimendağı Nap1 ile Erzincan Nap1 ve Munzur Kireçtaş1 tanımlanmıştır. Tersiyer-Kuvaterner yaşta olan örtü ise tektonik birliklerin üzerinde açılı uyumsuzlukla yer almaktadır.

\section{Yerel jeoloji}

Bölgenin yerel jeolojisi yöreye özgü stratigrafik özellikler, tektonik-sismisite ve diğer doğa kaynaklı riskler alt başlıkları altında sunulacaktır. Böyle bir sunumun, yörenin jeolojisi ile yöreyi tehdit eden doğa kaynaklı süreçler arasındaki ilişkinin anlaşılmasını kolaylaştırabileceği öngörülmektedir.

\section{Stratigrafik özellikler}

Çalışma alanı, Erzincan ovası ve yakın dolayını kapsamaktadır. İnceleme alanını temsil eden başlıca tektonik birimlere dair jeolojik harita Şekil 2'de, tektono-stratigrafik dikme kesitler ise Şekil 3'te görülmektedir.

Çimendağ1 Nap1, Liyas öncesi yaşta olan metamofik kayalar ve bu kayaları kesen granitlerin üzerine açılı uyumsuzlukla gelen Jura-Kretase yaşta olan ağırlıklı olarak çakıltaşı ve kumtaşında yapılı kayalar ve alt düzeyleri sı̆ denizel, üst kesimi yer yer pelajik kireçtaşlarından oluşmaktadır.

Erzincan Napı, ağırlıklı olarak peridoditlerle temsil edilen ofiyolit napları ve yer yer olistostromal nitelikte olan ofiyolitli karışıtan oluşmaktadır. Ofiyolitler Refahiye Karmaşı̆̆g, yer yer olistostromal olan ofiyolitli karışık ise Karayaprak Karışığı olarak adlandırılmıştır (Yılmaz, 1985). Ofiyolitler genel olarak karışığın üzerinde tektonik bir dokanakla yer almaktadır (Şekil 2).

Munzur Kireçtaşı ise ağırlıklı olarak platform türü karbonatlarla temsil edilmekte ve Erzincan Napı' nın altında yer almaktadır (Özgül, 1981). Üst Triyas - Alt Jura yaşta algli kireçtaş1 ile başlar, oolitli kireçtaşı, algli-foraminiferli kireçtaşı ve yer yer çakmaklı kireçtaşı ile devam eder. $\mathrm{Bu}$ birimin üst düzeylerindeki kireçtaşları üzerinde uyumlu ve keskin bir dokanakla Turoniyen-Kampaniyen yaşta çakmaklı pelajik kireçtaşı yer alır.

Örtüyü temsil eden Orta Eosen-Kuvaterner yaşta olan birimler, tektonik birimlerin üzerine açılı uyumsuzlukla gelir (Şekil 3). Orta Eosen yaşta olan kırıntılı istif üst düzeylere doğru önce volkano-tortul daha sonra masif volkanitlere uyumlu olarak geçer. Oligosen- Alt Miyosen yaşta olan karasal ve sı̆̆ denizel istif ise ağırlıklı olarak evaporitlerden oluşmakta ve daha eski tüm birimlerin kayaların üzerine açılı uyumsuzlukla gelmektedir. Bu birimler, yanal ve dikey yönde geçişli bir yap1 sunmaktadırlar. Erzincan Ovası'nın oldukça büyük bir bölümü Kuvartener yaşta olan birimlerden oluşmuştur. Havzada yaygın olan alüvyon yelpazeleri, yer altı suları için iyi bir akiferi temsil etmektedir. Kalınlıkları 50-150 m. arasında olan bu alüviyal malzemenin tabanında ofiyolitler yer almaktadırlar (Erzincan Valiliği, 2011). Sondaj verilerine göre, Erzincan havza dolgusunun kalınlığı yaklaşı $2 \mathrm{~km}$ kadardır (DSİ, 1981). 
Boz, Yılmaz
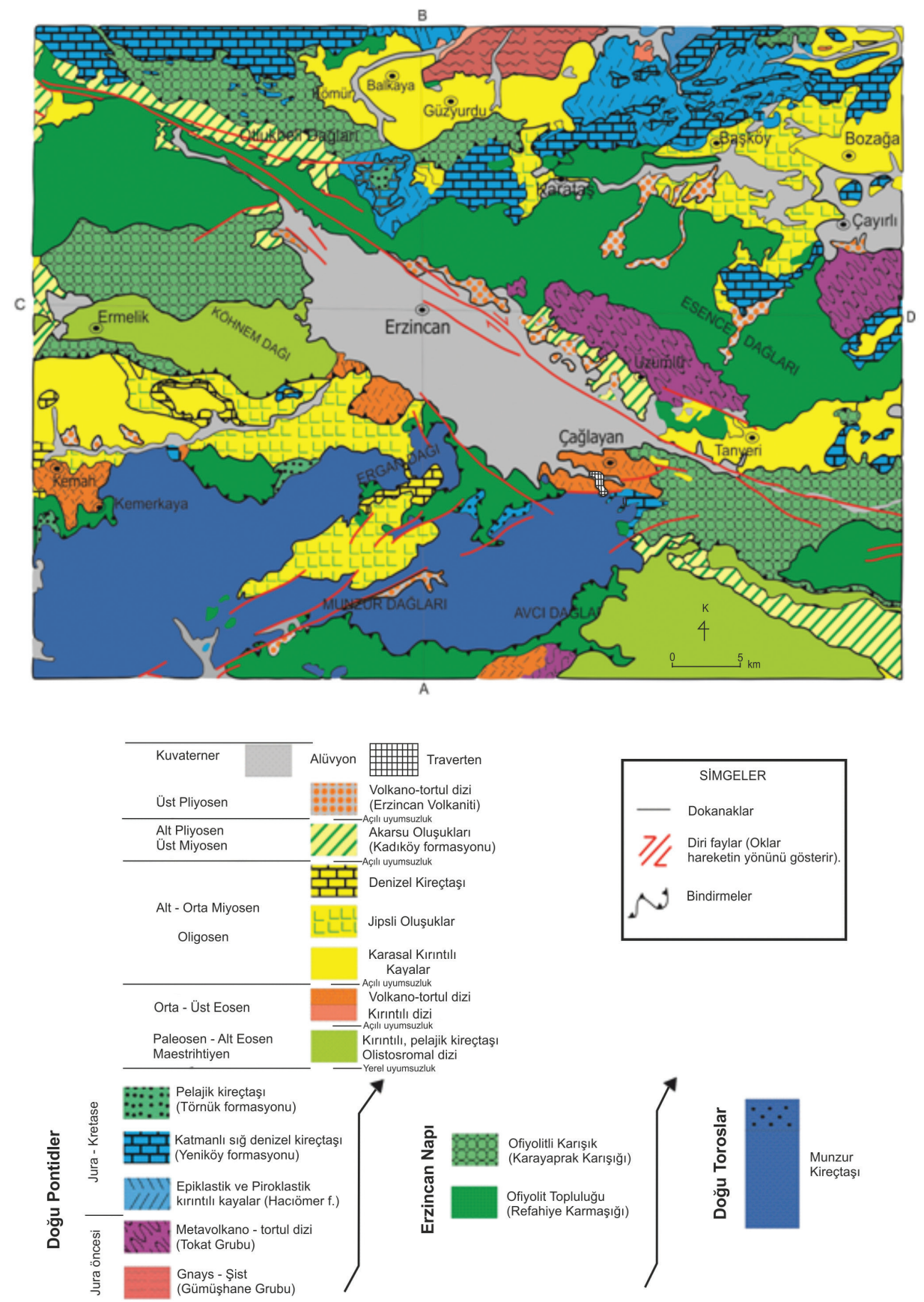

Şekil 2. Erzincan Ovası ve yakın dolayının jeoloji haritası (Özgül, 1981; Yılmaz, 1985; Aktimur vd., 1988; Koçyiğit, 1991'den).

Figure 2. Geologic map of the Erzincan Plain and its surroundings (After Özgül, 1981; Yllmaz, 1985; Aktimur et al., 1988; Koçyiğit, 1991). 


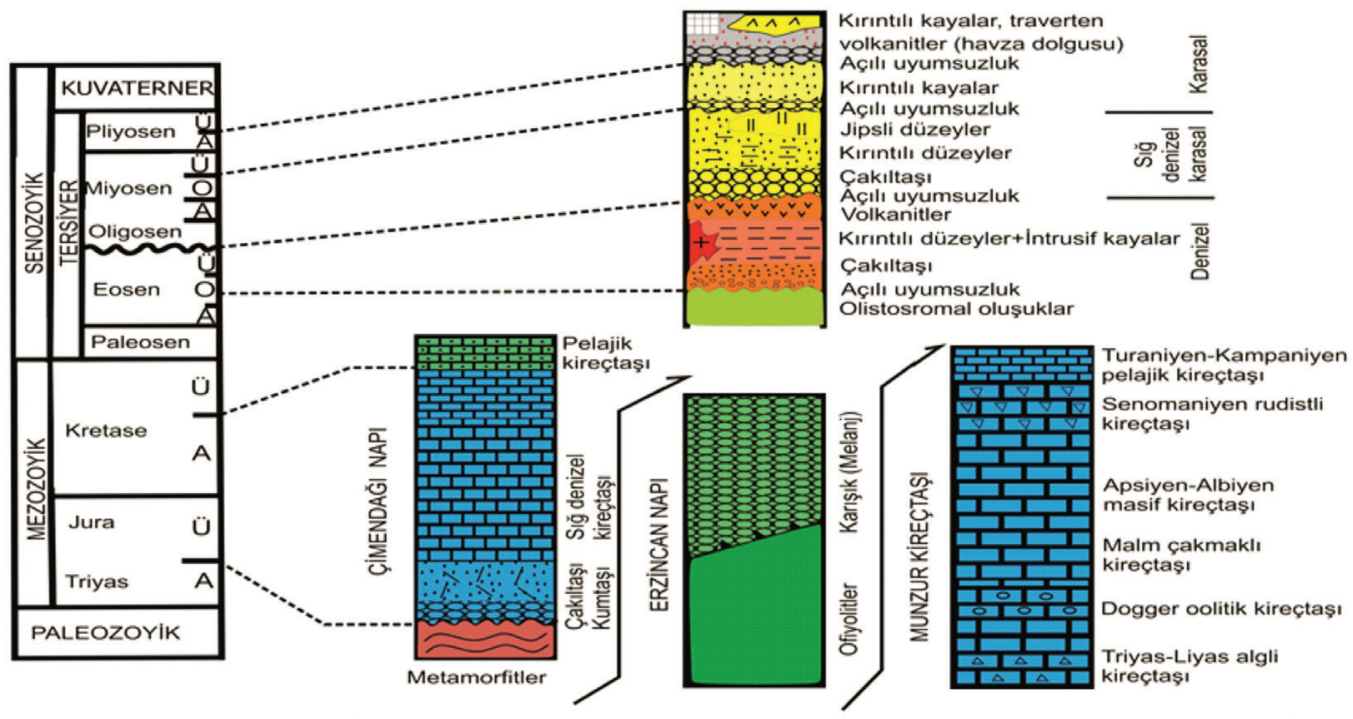

Şekil 3. Erzincan Ovası ve dolayının tektonik birlikleri ve havza dolgusu dikme kesitleri (Yılmaz, 1985'den).

Figure 3. Tectonic units and columnar sections of the basin fill of the Erzincan Plain and surroundings (After Yllmaz, 1985).

\section{Tektonik-sismisite/deprem}

Erzincan Ovası'nı karakterize eden ana faylar ve havzayı kuzeyden sinırlayan Kuzey Anadolu Fay Zonu'nun segmentleri ayrıntıl1 olarak incelenmiştir (Arpat ve Şaroğlu, 1975; Barka, 1984; Barka ve Gülen, 1989; Koçyiğit, 1991; MTA, 2003, 2012a). Erzincan Havzas1 ve yakın çevresindeki Kuzey Anadolu Fay Zonu üç segmente ayrılmış ve bu segmentlerden ikisi havza ve çevresinde gözlenmektedir. Doğu segment yaklaşı $75 \mathrm{~km}$ ve $\mathrm{K} 110^{\circ} \mathrm{D}$ doğrultusunda Yedisu-Tanyeri (Avcılar) arasında yer almaktadır. İki nolu segment ise havzanın kuzey sınırını oluşturmakta ve yaklaşık $60 \mathrm{~km}$ uzunluğunda olup K125을 doğrultuludur (Barka ve Gülen, 1989).

Bölgenin tektonik ve sismisitesini ortaya koymak üzere öncelikle bölgesel neotektonik döneme ait yapıların konumunu da irdelemekte yarar vardır. Şekil 1 ve 4'de Erzincan yöresinin önemli neotektonik yapıları görülmektedir. Kuzey Anadolu Fayı (KAF), Erzincan Ovası'nı kuzeyden sınırlar ve sağ yönlü doğrultu atımlı bir fay karakterindedir. Erzincan'ın güneyinde ise sol yönlü, kuzeydoğu-güneybatı doğrultulu ve birbirine koşut faylardan oluşan Ovacık Fay zonu (OF) yer almaktadır. Bu fayların tümü yaklaşık kuzey-güney doğrultulu bir sıkışmanın güdümünde oluşmuştur. Bu sistem makro olarak gözetildiğinde, Erzincan Ovası'nın da tıpk1 Karlıova gibi Anadolu levhasının batıya doğru devinimi ile açıldığı izlenimini vermektedir.

İnceleme alanı içerisindeki normal faylar havza kenarlarında yaygın olarak gözlenmekle birlikte, yer yer havza dolgusunu oluşturan genç birim içerisinde de gözlenmektedir. Bu faylar genellikle GD-KB ve D-B gidişli faylar olup bunun yanında bazı kesimlerde yaklaşı K-G gidişli olan küçük ölçekli faylar da yer almaktadır (Akpınar, 2010). 


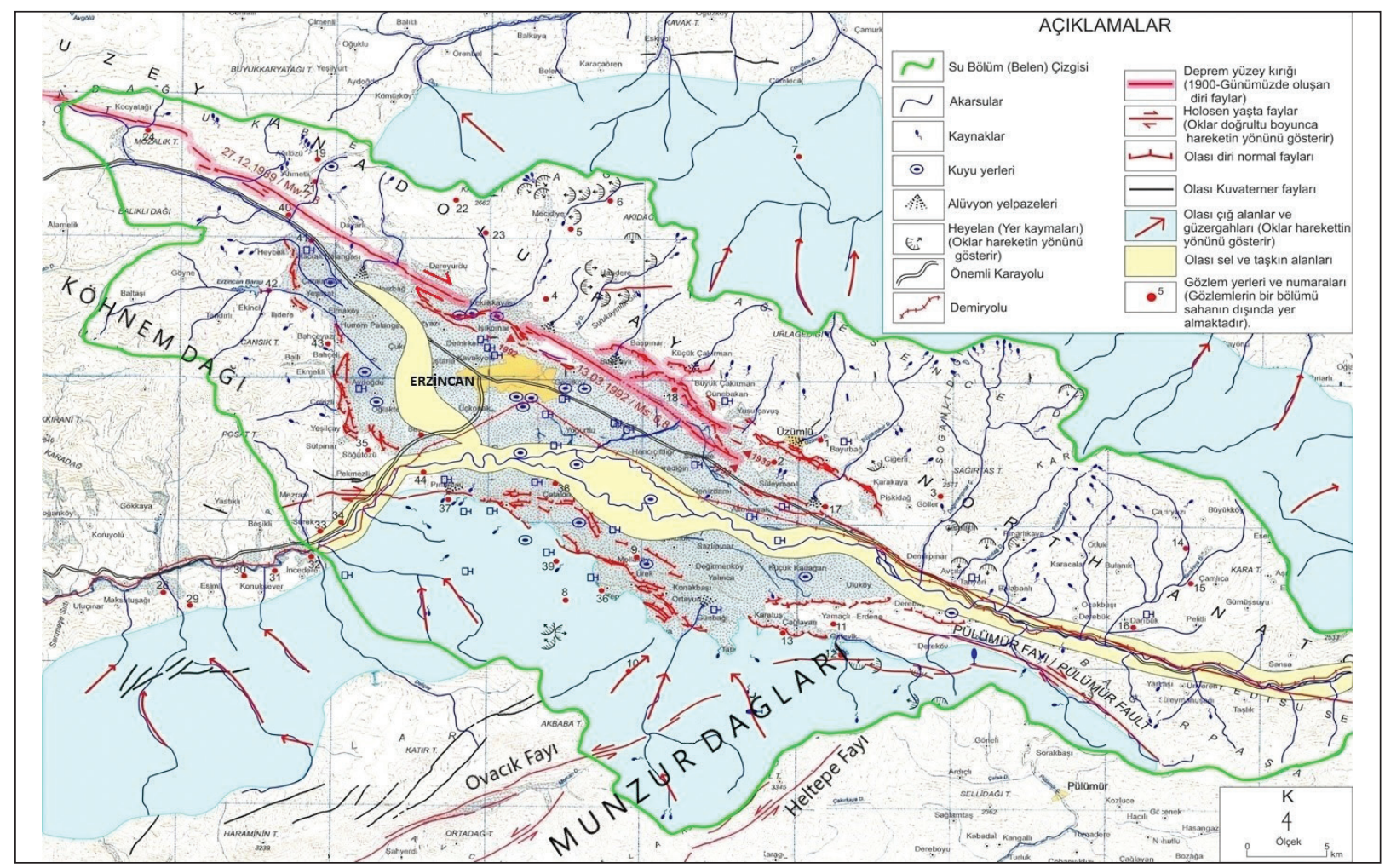

Şekil 4. Erzincan Ovası'nın su bölüm çizgisi, hidrojeolojik veriler ve doğa kaynaklı riskler haritası (DSİ,1981; Aktimur vd., 1988; MTA, 2012a' dan yararlanılmış ve yeni saha gözlemleri).

Figure 4. Hydrogeological data and natural disasters map of the Erzincan Plain (After DSI, 1981; Aktimur et al., 1988; MTA, $2012 a$ and new field observations).

Erzincan havzasinın kuzey kenarı halen aktif, güney kenarı kuzeye göre pasif rol oynamaktadır. KAF, Plio-Kuvaterner dönemde son şeklini almıştır. Buna göre havzanın KB kenarında, Plio-Kuvaterner yaşta konglomeraları üzerine serpantinlerin ters fayla gelmesi havzanın KB'sının kapanmakta olduğunu göstermektedir. Havzanın doğusunda ise, volkanik kayaların dağılımı ve fayların geometrisi, yersel bir açılma tektoniğinin (local pull-apart) varlığını ortaya koymaktadır.

Sonuç olarak, Erzincan Ovası'nın KAF'ın (yani sağ yanal doğrultu atımlı bir rejimin) ve dolayındaki diğer tektonik unsurların denetiminde gelişmiş kıta içi bir havza olduğu ve günümüzde de K-G doğrultulu bir sıkışmanın denetiminde oluşumunu sürdürdüğü kabul edilebilir.

Erzincan yöresinde son 1000 y1l içinde şiddeti 7' den daha büyük 10'dan fazla deprem yaşanmıştır (Erzincan Valiliği, 2011; Boz, 2015). 27 Aralık 1939 depremi, 20. yy'da yeryüzünde görülen 15 büyük depremden biridir. $\mathrm{Bu}$ depremde 32.968 kişi ölmüş, 4.125 kişi de ağır yaralanmıştır. 14.401 bina yıkılmış, 4.043 bina da ağır hasara uğramıştır. İl merkezinde 7.206 binanın 6.601 'i yıkılmış, geriye kalanı ise tren istasyonu binası hariç kullanılamaz hale gelmiştir. Erzincan il sınırları içinde 5 adet deprem ölçüm istasyonu bulunmaktadır. Günlük 
yer hareketleri Ankara'da bulunan Afet ve Acil Durum (AFAD) Başkanlığı tarafindan 24 saat izlenmektedir (Erzincan Valiliği, 2011).

\section{Doğa kaynaklı ve diğer riskler}

Erzincan ovas1 ve dolayını tehdit eden doğa kaynaklı diğer riskler başlıca heyelanlar, çığlar, sel ve taşkınlar, erozyon, fırtınalar ile orman ve otlak yangınlarıdır. Aşağıda, Erzincan Valiliği (2011) tarafında derlenmiş olan veriler, arazide yapılan gözlemler çerçevesinde değerlendirilmiştir. Yapılan değerlendirmeye dair Erzincan Ovas1 ve dolayının su bölüm çizgisi, bazı önemli hidrojeolojik veriler ve yöreyi tehdit eden doğa kaynaklı riskler Şekil 4'de sunulmuştur.

Heyelanlar, daha geniş anlamda, yamaç hareketleri terimini kullanarak bir siniflama yapan Varnes (1978) dönel/yanal kaymalarına karş1lık gelmektedir. Doğal Risk Haritasında (Şekil 4) heyelanların tümünde yere özgü kopma yerleri ve kayma yönü görülmektedir. Elbette gereçlerin biriktiği bir alan da vardır. Bir heyelan olayına jeoloji, jeomorfoloji, iklim ve bitki örtüsü ile insan kaynaklı etkenlerden biri veya bir kaçı neden olabilir. Heyelanlar genelde, deprem ve/veya aşırı yağışların tetiklemesiyle dünyada en fazla can ve mal kaybına yol açan olayların arasında yer almaktadır. Erzincan ovası ve dolayında heyelan oluşturan birimler yaygındır (Şekil 4). Özellikle Tersiyer yaşta olan birimlerde heyelanlar sıç̧a görülmektedir. $\mathrm{Bu}$ kapsamda, Erzincan Ovası'nın kuzey bölgesinde yer alan Esence Dağları bitki örtüsünden yoksun olması nedeniyle heyelan tehlikesiyle karşıkarşıyadır. Aynı şekilde, ovanın güneyinde yer alan Munzur Dağları'nın kuzey yamaçlarında masif ya da kalın katmanlı kireçtaşları eklemli ve kırıklı yapıya sahip olmaları nedeniyle, bu yamaçlarda kimi zaman kaya düşmeleri ya da devrilmeleri yaşanmaktadır (Şekil 4).
Çığlar, bir yamaçta mevcut dengenin bozulması ile kar katmanlarının, yamaç eğimi yönünde akması ile oluşur. Yamaç eğimi, bitki örtüsü, meteorolojik koşullar, kar tabakasının yapısı, yapay etkiler çığın oluşmasına neden olan faktörlerdir. Erzincan'da 2000 y1lı içerisinde Refahiye ilçesi, Mendeme başı Köyü, Bektaşi Mezrası ve İliç İlçesi, Çöpler Köyü olası çı̆̆ tehlikesinden dolayı etüt programlarına dahil edilmiştir. Şekil 4'de izlenen çığ güzergâhları, yamaç eğiminin 25-35 derece olduğu ve çığa dair diğer unsurların da gözetildiği vadilere karşıllık gelmektedir.

Erozyon açısından da, bölge açısından da tehdit altındadır. Ova'nın kuzeyindeki ve güneyindeki dağların yüksek olan yerleri, erozyonun en yoğun olduğu yerlerdir. Ayrica bölgede çoğu yerde, toprağın A horizonu taşındığından daha açık renkli $\mathrm{B}$ horizonu yüzeye çıkmış bulunmaktadır. Donma-çözülme olayları erozyonu arttırmaktadır. İl merkezi ve yakın dolayındaki yapılaşmanın da erozyonun artmasında etkili olduğu söylenebilir. Ekolojik dengenin bozulması ve aşırı otlatma, erozyonun bölgede etkili olmasının diğer faktörlerdir. Erozyon ile çevredeki yamaçlardan ovaya çok fazla malzeme taşınmaktadır. Taşınan kırıntılı kayalar eteklerdeki verimli tarım alanlarını örtme eğilimindedir. Özellikle Pliyosen-Pleyistosen arazisinde kaynaklanan çakıllı kırıntılar tarım alanlarını etkilemektedir. Erozyonunun olduğu kesimlerde teraslama yapılmalıdır. Teraslara bölgenin ekolojik şartlarına uygun ağaçlar dikilmelidir. Ayrıca yamaçlarda yapay (kuru duvar, çit vs.) bentler yapılmalıdır.

Sel ve taşkınlar da Erzincan Ovası'nın orta kesimini önemli boyutlarda tehdit etmektedir (Şekil 4). Bölgede yaşanan taşkınlar meteorolojik verilere göre en çok Mart - Nisan - Mayıs - Haziran ve Temmuz aylarında 
meydana gelmektedir. Mevcut durumda Yukarı Firat Nehri'nin Erzincan Ovası'nın ortasından geçmesi sebebiyle nehre yakın yerleşim yerleri, 100 yılda ve 500 yılda gelen ve 2 saat süren taşkınlara karşı savunmasız durumdadır.

Orman ve otlak yangınları her yerde ağırlıklı olarak birer insan kaynaklı tehdittir. Erzincan ilinde, 1989 yılında 3, 1993 - 2010 yılları arasında toplam 29 adet yangın çıkmış bu yangınlar sonucunda 147.81 hektar ormanlık alan tahrip olmuştur (Boz, 2015).

\section{Erzincan Ovası ve Dolayının Hidrojeolojik Özellikleri}

Erzincan Ovası ve yakın dolayı Yukarı Firat Havzasında yer almaktadır. Şekil 4' de Erzincan Ovası'nın su bölüm çizgisi ve ovayı besleyen önemli kaynakların dağılımı görülmektedir. Bölgenin yüzey ve yeraltı su kaynakları DSİ (1981) tarafindan kapsamlı olarak ayrı ayrı değerlendirilmiştir.

\section{Yüzey sulart}

Erzincan ilinin yüzey su kaynakları başlıca kaynaklar (pınarlar), akarsular, maden suları, barajlar, göller ve yapay göletlerle temsil edilmektedir. Ovanın en önemli yüzey suyu kaynakları Fırat nehri, Kirnavik dere, Şıhlı sulamasındaki azmaklar ile Çardaklı deresidir. Erzincan ovasındaki suların sınıfı genellikle $\mathrm{C}_{2} \mathrm{~S}_{1}$ olup hafif tuzlu olup ve düşük düzeyde alkali niteliğe sahiptir. Şu anda su gereksinimini karşılamak için kullanılan su kaynakları aynı zamanda il genelinde üretilen atıkların depolandığı Katı Atık Depolama Tesisinin sızıntı sularından etkilenme tehlikesiyle karşı karşıyadır. Özellikle akarsular bu kirlilikten en çok etkilenen ve önlem alınmazsa daha da büyük zararların oluşmasına yol açabilecek bir konumdadır (Erzincan Valiliği, 2011).

\section{Yeralt sulart}

Bölgenin akiferi, Ova'nın güneyinde yer alan Mesozoik yaşta olan Munzur kireçtaşları ile ovadaki alüvyon ve alüvyon konileridir (Şekil 4). Alüvyon ve alüvyon konilerinin yayılımı 494 km²'lik bir alan kaplamaktadır. Genellikle iri malzeme olan kum ve çakıllardan oluşan alüvyon ve alüvyon konilerin kalınlıkları 50-150 metre arasında değişmektedir. Ova ortasında 200 $\mathrm{km}^{2}$ 'lik bir alanda yer yer killi düzeyler nedeniyle akifer, basınçlı akifer özelliğini göstermektedir.

Yeraltı su tablası ovanın büyük bir kısmında yüzeye çok yakın ya da yüzeydedir. Bu yüzden özellikle vadi tabanında yer yer bataklık ve sazlıklar gelişmiştir. Büyük Çakırman köyü sahasının güneyi, Erzincan Ovası'nın güneyinde yer alan araziler bataklik olup, yeraltı su tablasının yüzeyde bulunduğu sahalardır (Şekil, 4). Yeraltı su tablası derinlik haritas1, arazi kullanım potansiyel haritalarının yapımında önemli bir faktör olup, yerleşim yerlerinin ve yol güzergâhlarının yanı sıra atık maddelerin atılacağ1 sahaların belirlenmesinde kullanılabilir. Yeraltı sularının derinliğine dair ölçümlerin tüm yıl boyunca sürekli yapılıp izlenmesi gerekir.

\section{Erzincan Ovası'nın Jeomorfolojisi}

Erzincan Ovas1, kuzeyinde ve güneyinde yüksek dağlarla çevrili bir platonun üzerinde yer alır. Ovanın Su Bölüm Çizgisi dâhilindeki arazinin \% 60'1 dağlardan oluşur. Dağlar, çeşitli doğrultularda, kendine özgü kuzeyde yaklaş1k KB-GD uzanımlı; güneyde ise GB- KD uzanımlı bir düzen içinde yer alır. Örneğin güneybatıdan Munzur dağları, batıdan Köhnem Dağı il alanına girer (Şekil 4). Doğudan Erzurum'dan gelerek batıya doğru uzanan Karasu, ilin ova alanını derinlemesine, aralarında geniş düzlükler bırakacak şekilde geçer. Ayrıca bölgenin eğim haritaları oluşturulmuştur (Boz, 2015). 
Erzincan Ovası'nın kuzeyindeki dağlar $3349 \mathrm{~m}$, güneyindeki dağlar ise $3462 \mathrm{~m}$ yüksekliklere ulaşmaktadır. Ovanın deniz düzeyinden ortalama yüksekliği yaklaşık 1180 m'dir. Çevresindeki yükssek dağlarla ova yüksekliği arasında düzey farkı 1800 m'yi geçer. Ovanın kuzeybatı-güneydoğu yönündeki uzunluğu $50 \mathrm{~km}$, eni ortalama $18 \mathrm{~km}$ kadardır. $\mathrm{Bu}$ konumu ile Erzincan Ovası örnek bir dağlar arası havzadır. Ovanın yüzölçümü $600 \mathrm{~km}^{2}$, kodu 1150-1300 $\mathrm{m}$ arasında değişmektedir.

Erzincan il merkezinin etrafinın dağlarla çevrili olması nedeniyle özellikle kış aylarında rüzgâr hızının yetersiz olduğu, dolayısıyla hava kirliliğinin sürekliliğine yol açan tersinmenin (inversiyonun) oluştuğu ya da yağışın olmadığı dönemlerde kimi zaman hava kirliliğinin yaşandığ 1 bilinmektedir (Erzincan Valiliği, 2011).

\section{Doğal Kaynaklar}

Bölgenin başlıca doğal kaynakları, toprak, maden yatakları, yukarıda sunulan su kaynakları ve ormanlık alanlar olarak sayılabilir.

Toprak, bölgenin en önemli doğal kaynağ1 olup, inorganik (\%45), organik (\%05), su (\%25) ve hava (\%25) içermekte (Erzincan Valiliği, 2011) ve yaşamın temelini oluşturmaktadır. İklim, topografya ve ana gereç farklılıkları nedeniyle Erzincan ilinde çeşitli toprak grupları oluşmuştur. Büyük toprak gruplarının yanı sıra toprak örtüsünden yoksun bazı arazi tipleri de görülmektedir (Boz, 2015).

Erzincan ili ve il sınırları içinde yer alan bölge, jeolojik açıdan zengin bir kayatürü çeşitliliğine sahiptir. $\mathrm{Bu}$ zenginlik bölgenin maden yatakları açısından zengin olmasının temelini oluşturur. Maden yatakları metalik madenler, sanayi hammaddeleri ve enerji kaynakları açısından irdelenmiştir (MTA, 2012b). Maden yataklarının türleri ve bölgedeki dağılımı Şekil 5'de görülmektedir.

Erzincan İli metalik madenler, özellikle krom yatakları bakımından oldukça zengindir. İlin batısındaki Tercan, kuzeybatısındaki Refahiye, güneybatısındaki İliç ve güneyindeki Kemah İlçelerinde krom kaynakları bulunmaktadır. İliç ve Kemaliye İlçelerinde demir, İliç, Kemaliye ve Çayırlı İlçelerinde ise manganez kaynakları bulunmaktadır. Ormanlık alanlar ise aşağıda mevcut arazi kullanımı bölümünde irdelenmiştir.

\section{Mevcut Arazi Kullanımı}

Erzincan Ovası ve dolayı birlikte gözetilerek, mevcut arazi kullanım biçimlerinin alansal dağılımı Şekil 6'da sunulmuştur. Buna göre Erzincan ilinin yakın dolayı ormanlık alanlardan ve ikinci dereceden ağaçlandırılması gereken alanlardan oluşmaktadır. İl merkezine yakın yerlerde kuru tarım alanları, sulu tarım alanları yaygın olarak görülmektedir. Ova'nın ortasından Fırat Nehri geçtiğinden bu nehre yakın yerleşim yerleri taşkın tehlikesi altındadır. Ayrıca ovanın çeşitli yerlerinde sazlıklar görülmektedir. Ancak bu sazlıkların korunmasına karşın hiçbir önlem alınmadığından sazlıklar, kuruma tehdidi ile karşı karşıyadır.

Çevre ve Şehircilik Bakanlığı (2012) tarafından güncelleştirilen iller bazındaki çevre durum raporuna bakıldığında, Erzincan için hava ve su kaynakları kalitesi, atık sorunu, tabiat varlıkları ile doğa ve biyo-çeşitliliğin korunması, arazi kullanımı ve yapılan denetimler görülebilir. Mevcut verilere göre Erzincan ili sınırları içinde yer alan arazinin \%17'si tarım, $\% 9$ orman ve fundalık, $\% 38$ çayır ve mera, $\% 36$ tarım dışı alan olarak kullanılmaktadır (Erzincan Valiliği, 2011). Yerleşim, tarım, orman ve diğer alanlarının dağılımı Şekil 6'da görülmektedir. 
Boz, Yılmaz
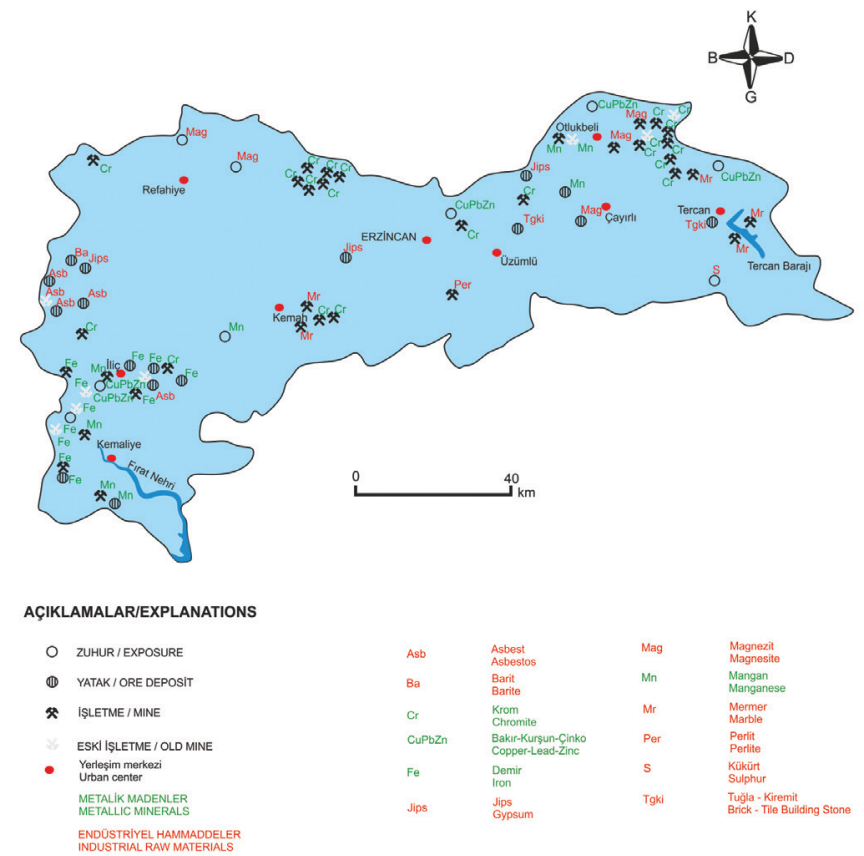

Şekil 5. Erzincan İli maden yatakları haritası (MTA, 2012b).

Figure 5. Mineral deposits map of the Erzincan Province (MTA, 2012b).

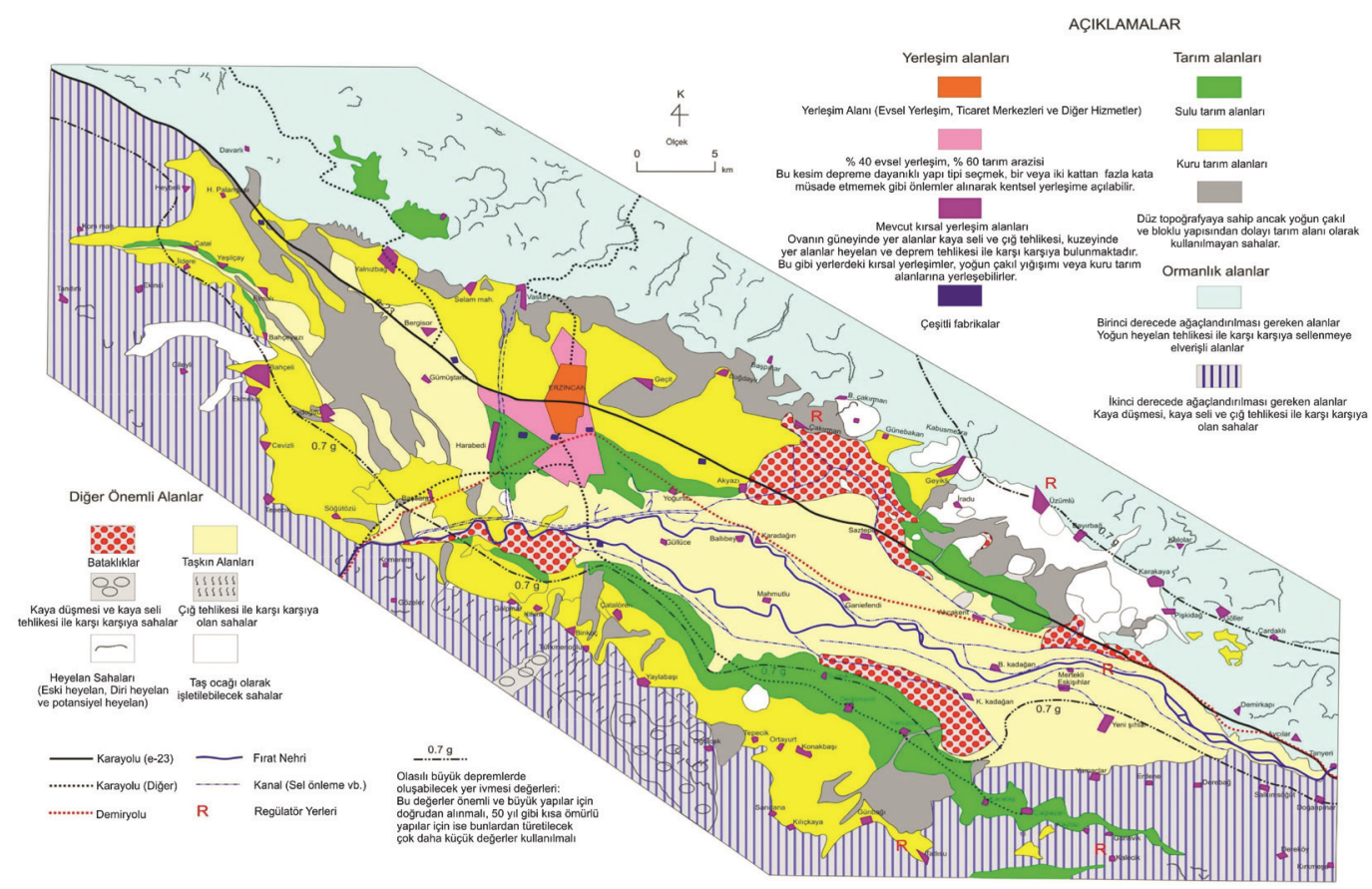

Şekil 6. Erzincan Ovası ve dolayının arazi kullanım potansiyel haritası (Aktimur vd., 1988'den).

Figure 6. Land-use potantial map of the Erzincan Plain and surroundings (After Aktimur et al., 1988). 
İstatistiksel verilere göre, arazi kullanım değişikliği en çok tarımsal alanların azalmasına yol açmıştır. Bunun başlıca nedeni, tarım arazilerinde yeni yerleşim birimlerine açılmasıdır. Özellikle son 20 yıl içinde İmar Yasası'nda değişiklikler yapılmış ve 1. Sınıf tarım alanları çeşitli amaçlarla kamulaştırılmış olup, iskâna açılmıştır.

İl bazında hava kirliliğinin daha çok 1sınmadan ve trafikten kaynaklanan emisyonlardan oluştuğu ve yapılan ölçümlere göre $\mathrm{SO}_{2}$ ve partikül maddeden kaynaklanan kirleticilerin yönetmeliklerde tanımlanan sinır değerlerini aşmadığı söylenebilir (Erzincan Valiliği, 2011). Son yıllarda yenilenebilir enerjiye yönelik çabaların yanı sıra ağaçlandırma çalışmalarının yapılması olumlu gelişmelerdir. Hidrojeoloji kısmında değinilmişti ve bu başlıkla ilişkisi bulunmamaktadır. Erzincan il merkezinde kanalizasyon şebekesi atık su arıtma tesislerine bağlanmıştır. Tarımsal faaliyetler için sulamada yüzeysel sulama sistemleri kullanılmaktadır. Atık miktar1 günlük ortalama $1.40 \mathrm{~kg} / \mathrm{kişi} /$ gün olarak hesap edilmiştir. Evsel nitelikli atıklar Terzi baba mevkii dolayında vahşi depolama alanında uzaklaştırılmaktadır (Erzincan Valiliği, 2011). Erzincan'da tehlikeli atıklar ise lisanslı araçlarla Atık Geri Kazanım ve depolama tesislerine gönderilmektedir.

\section{ERZINCAN OVASI'NIN ÇEVRE JEOLOJISI}

Yukarıda sunulan mevcut duruma dair çerçeve gözetilerek Erzincan ovası ve yakın dolayının çevresel sistemleri ve çevresel birimleri tanımlanmıştır. Çevresel sistemlerin yalınlaştırılmış haritası Şekil 7'de sunulmuştur. Şekil 7'de görüldüğü gibi, Erzincan Ova Sistemi ile Ergan Dağ1 Sistemi birlikte, yer yer İnsan
Faaliyetleri Sonucu Değişime Uğramış Sistem tarafından değişime uğramıştır. Dolayısıyla bu örtüşmeyi aşmak üzere, İnsan Faaliyetleri Sonucu Değişime Uğramış Sistem, kendi özelinde değişimi karakterize eden simgelerle ayrıştırılmıştır. Çizelge 1'de ise çevresel sistemler ve her çevresel sisteme ait çevresel birimler yer almaktadır. Sistemlerin adlandırılması, sistemin egemen olarak bulunduğu yerin coğrafik adı ve yapısı gözetilerek yapılmıştır. Çevresel birimler ise kaya türü özelliklerinin benzerliği, çevresel açıdan işlevi ve mevcut arazi kullanım biçimi gözetilerek tanımlanmaktadır. Ayrıntılı çevre jeolojisi haritası da Şekil 8'de sunulmuştur. Çevresel sistemler aşağıdaki sıra gözetilerek ele alınmıştır:

1) Erzincan Ova Sistemi,

2) Ergan Dağ1 Sistemi,

3) İnsan Faaliyetleri Sonucu Değişime Uğramış Sistem.

\section{Erzincan Ova Sistemi}

$\mathrm{Bu}$ sistem, ağırlıklı olarak Erzincan havzasının çökel dolgusu ve dolguyu besleyen yapılarla temsil edilmektedir. Başlıca birimler genç volkanitler, traverten, havza dolgusu (Üst Pliyosen-Kuvaterner yaşta kırıntılı kayalardan yap1lı olup, kendi içinde tane boyutlarına göre alt bölümlere ayrilabilmektedir), alüvyon yelpazeleri (Akarsu ve derelerin ovaya kavuştuğu yerler), sazlıklar, kaynaklar ve akarsularla temsil edilmektedir. Sistemi karakterize eden birimlere dair bazı görüntüler Şekil 9'da görülmektedir. Söz konusu birimler, başlica yamaç eğimi, bitki örtüsü, toprak kalınlığı, gerecin (yani kayanın) türü ve günümüzdeki arazi kullanım biçimleri yönü ile incelenmiştir (Çizelge 2). 
Boz, Yılmaz
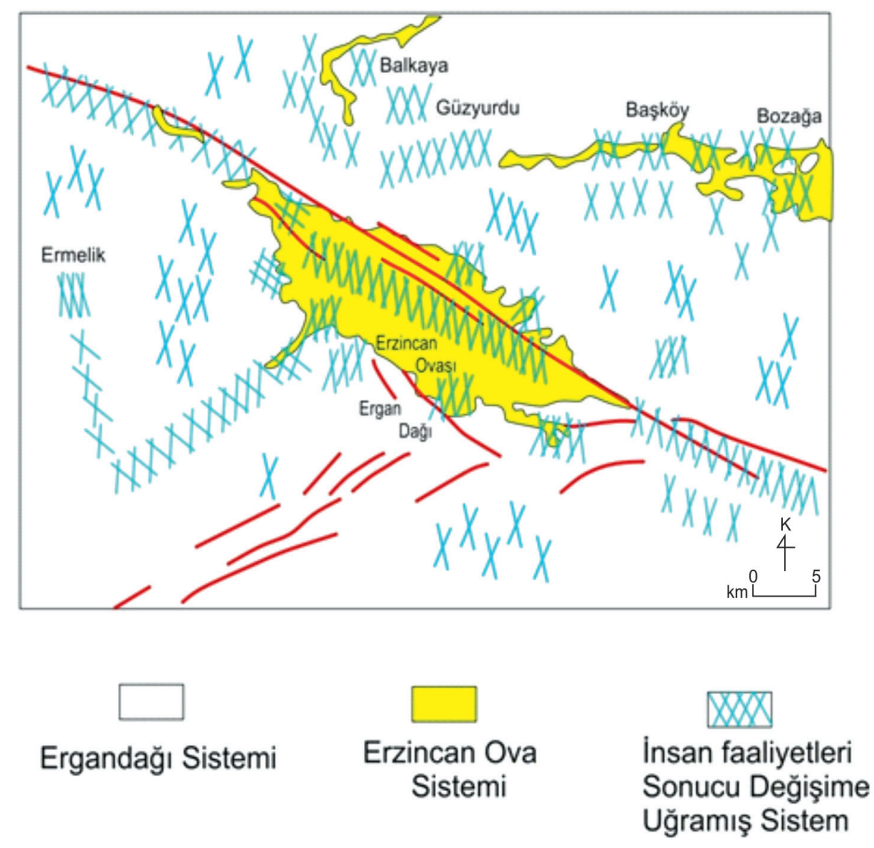

Şekil 7. Erzincan Ovası ve dolayının yalınlaştırılmış çevresel sistemleri.

Figure 7. Simplified environmental systems of the Erzincan Plain and surroundings.

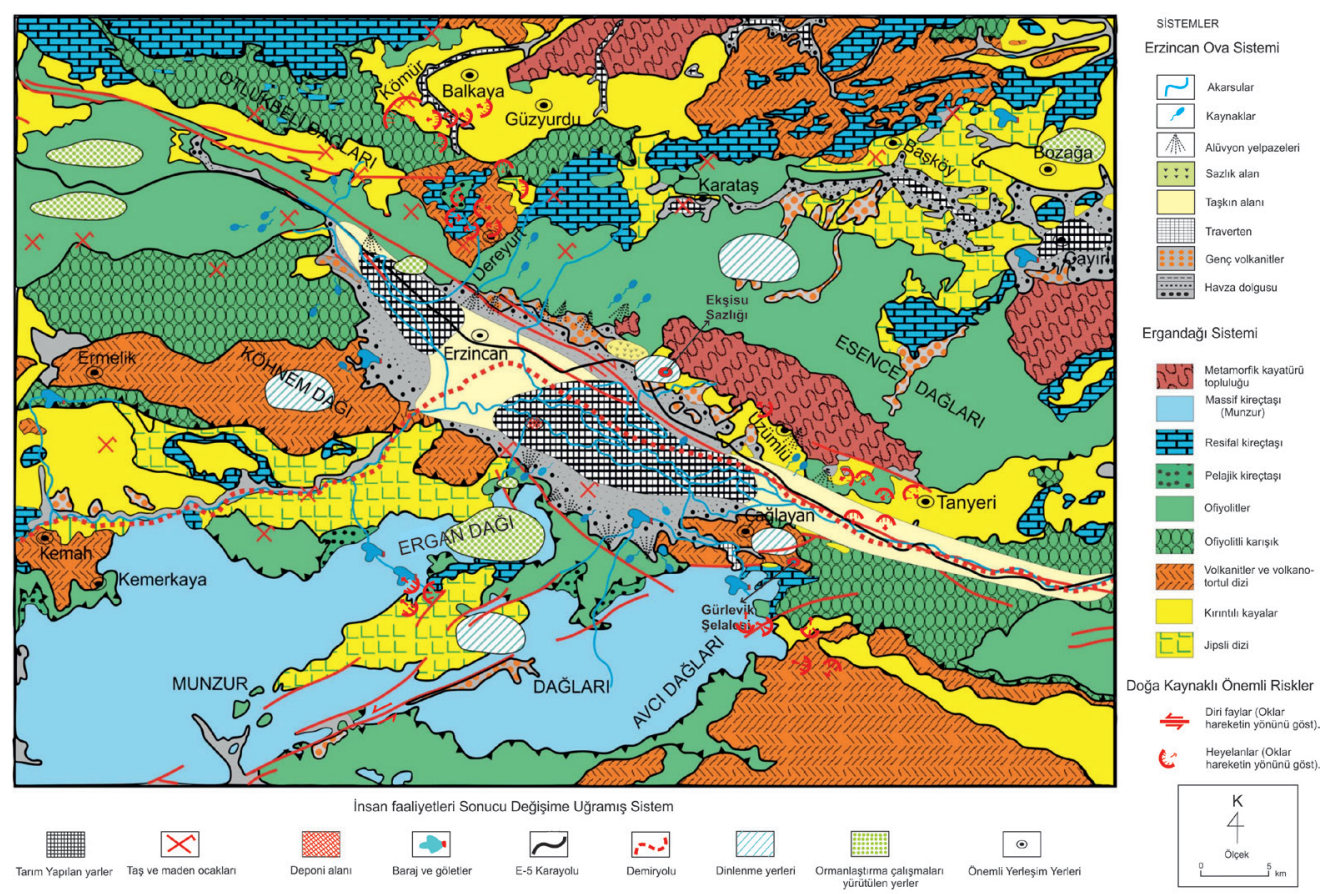

Şekil 8. Erzincan Ovası ve dolayının çevre jeolojisi haritası.

Figure 8. Environmental geological map of the Erzincan Plain and surroundings. 

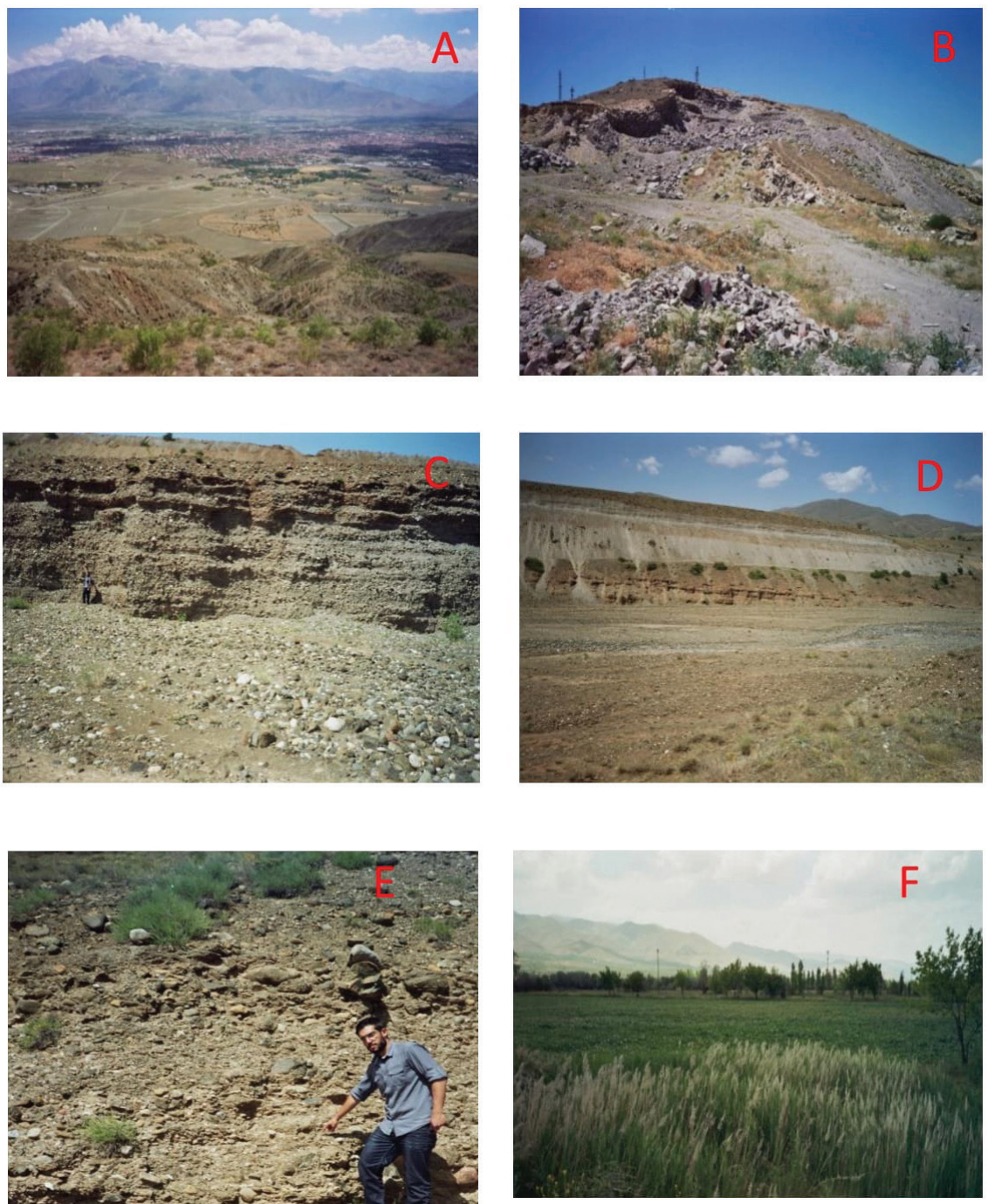

Şekil 9. Erzincan Ova Sistemi’nde yer alan çevresel birimlerden bazı görüntüler (A, Erzincan'ın kuzeyinden güneye doğru bir bakış, Ova’nın genel görünümü; B, Erzincan’ın kuzey kesimi, Üzümlü ilçesi dolayı andezit-dasit bileşimli Pliyosen yaşta genç volkanitler; C, Heybeli-Davarlı arası, Erzincan Ovası havza dolgusundan bir görüntü, iri taneli kırıntılı kayalar (Çakıltaşı); D, Heybeli-Davarlı arası, Erzincan Ovası havza dolgusundan bir görüntü, orta ve ince taneli kırıntılı kayalar (Kumtaşı ve kiltaşı ardalanması); E,Heybeli-Davarlı arası, Erzincan Ovası havza dolgusundan bir görüntü, iri taneli kırıntılı kayaların (Çakıltaşının) yakından görünümü; F, Beşsaray dolayı, Yukarı Fırat’a yakın sazlik bir alan).

Figure 9. Views from environmental units in the Erzincan Plain System (A, A view from the north of Erzincan to the south, the general view of the plain; B, Young volcanics of andesite-dacite composition of Pliocene age, to the northern part of Erzincan around Üzümlü district; $C$, A view from Erzincan Plain basin fill, the coarse-grained clastic rocks (Conglomerate) between Heybeli-Davarl villages; D, A view from Erzincan Plain basin fill, medium to fine-grained clastic rocks (Sandstone and claystone alternation) between Heybeli-Davarll villages; E, A close view from coarse clastic rocks (Conglomerate), from Erzincan Plain basin fill, between Heybeli-Davarll villages; F, $A$ morass area, near the Upper Euphrates around Beşsaray village). 
Boz, Yılmaz

Çizelge 1.Erzincan ovası ve dolayının çevresel sistemleri ve çevresel birimleri.

Table 1. Environmental systems and environmental units of the Erzincan Plain and surroundings.

\begin{tabular}{|c|c|}
\hline \multicolumn{2}{|c|}{ 1- Erzincan Ova Sistemi (Erzincan Plain System): } \\
\hline & Genç volkanitler \\
\hline & Traverten \\
\hline & Havza dolgusu (Üst Pliyosen-Kuvaterner yaşta kırıntılı kayalar). \\
\hline & İri taneli moloz ve çakıltaşı \\
\hline & Orta taneli kırıntılı kayalar (Ağırlıklı olarak kumtaşı). \\
\hline & İnce taneli kayalar (Kiltaşı, silttaşı, çamurtaşı). \\
\hline & Alüvyon yelpazeleri (Akarsu ve derelerin ovaya kavuştuğu yerler) \\
\hline & Sazlıklar \\
\hline & Kaynaklar \\
\hline & Akarsular \\
\hline & Taşkın alanı \\
\hline \multicolumn{2}{|c|}{ 2- Ergandağı Sistemi (Ergan Mountain System): } \\
\hline & Metamorfik kayalar (Şist, gnays, metavolkanit, serizitşist, kalkşist, mermer). \\
\hline & Masif kireçtaşı (Munzur kireçtaşı). \\
\hline & $\begin{array}{l}\text { Resifal kireçtaşı (Sığ denizel ortamın ürünü kırıntılı yer yer marnlı orta ve kalın katmalı } \\
\text { kireçtaşı). }\end{array}$ \\
\hline & Pelajik kireçtaşı (İnce kırıntılı pelajik fosiller içeren ve ince katmanlı kireçtaşı). \\
\hline & Ofiyolitler (Ağırlıklı olarak serpantinleşmiş peridodit). \\
\hline & Ofiyolitli karışık yer yer olistostromal kırıntılı kayalar \\
\hline & Kırıntılı kayalar (Çakıltaşı, kumtaşı, kiltaşı ve şeyl ardalaması). \\
\hline & $\begin{array}{l}\text { Volkanitler ve volkano-tortul dizi (Andezit, bazalt ve yer yer dasit bileşimli volkanitler ve } \\
\text { epi-piroklastik kayalar egemen). }\end{array}$ \\
\hline & Evaporitler (Jips, anhidrit ve diğerleri) \\
\hline \multicolumn{2}{|r|}{ 3- İnsan Faaliyetleri Sonucu Değişime Uğramış Sistem (Man-made or Antropogenic system) } \\
\hline & Tarım yapılan yerler (Ova ve yamaç üstü düzlükler, teraslar) \\
\hline & Taş ve maden ocakları (Mermer, kireçtaşı, kum ve maden ocakları) \\
\hline & Deponi alanları \\
\hline & Baraj ve göletler \\
\hline & Karayolları \\
\hline & Demiryolları \\
\hline & Dinlenme yerleri (Girlevik Şelalesi ve Ekşisu Sazlığı) \\
\hline & Ormanlaştırma çalıştırması yürütülen yerler \\
\hline & Yerleşim yerleri \\
\hline
\end{tabular}




\section{Ergan Dağı Sistemi}

$\mathrm{Bu}$ sistem genel olarak Erzincan Ovası ve ovanın yakın dolayında yüzeylenen kayatürü toplulukları ile temsil edilmektedir. Çevresel birimler, jeolojik yaşları dikkate almadan, yöreye özgü kayatürlerinin benzer özellikleri gözetilerek tanımlanmıştır. Söz konusu birimler, metamorfik kayalar, masif kireçtaşı, resifal katmanlı kireçtaş1, pelajik kireçtaş1, ofiyolitler, ofiyolitli karışık, kırıntılı kayalar, volkanitler ve volkanotortul dizive evaporitler olarak tanımlanmıştır (Çizelge 2). Sisteme dair bazı görüntüler Şekil 10 'da sunulmuştur. Ayrıca bu birimler de yamaç eğimi, bitki örtüsü, toprak kalınlığ 1 , gerecin (yani kayanın) türü ve günümüzdeki arazi kullanım biçimleri yönü ile incelenmiştir.

\section{İnsan Faaliyetleri Sonucu Değişime Uğramış Sistem}

$\mathrm{Bu}$ sistem, tümüyle insan faaliyetleri ile değişime uğramış, mevcut arazi kullanım biçimleri gözetilerek tanımlanmıştır. Sistem başlıca tarım yapılan yerler (ova ve yamaç üstü düzlükler ve teraslar dâhil), taş ve maden ocakları (mermer, kireçtaşı, kum ve maden ocakları), deponi alanları, baraj ve göletler, karayolları, demiryolları, dinlenme amaçlı yerler ve ormanlaştırma çalışmalarının yürütüldügüü yerlerle temsil edilmektedir. Sisteme dair baz1 görüntüler Şekil 11'de görülmektedir. Bu sistemi temsil eden birimlerin genel özellikleri Çizelge 1'de, birimlerin genel özellikleri, başlıca yamaç eğimi, bitki örtüsü, toprak kalınlığı, gerecin (yani kayanın) türü ve günümüzdeki arazi kullanım biçimleri Çizelge 2'de sunulmuştur.

\section{ERZINCAN OVASI'NIN ARAZI YETENEK DEĞERLENDİRMESİ}

Arazi yetenek değerlendirmesi için temel jeolojik özelliklerin ve jeolojik birimlerin hidrojeolojik davranışlarının yanı sıra bu birimlerin jeoteknik- mühendislik özelliklerinin ve yöreye özgü doğa kaynaklı risklerin göz önüne alınması zorunludur. Yukarıda mevcut duruma dair bilgiler sunulmuştur. $\mathrm{Bu}$ bölümde ise bölgeye ait çevresel birimlerin jeoteknikmühendislik özellikleriyle doğa kaynaklı risklere dair bilgiler (Çizelge 3) irdelendikten sonra, tüm veriler kullanarak arazi yetenek değerlendirmesi (Çizelge 4) hazırlanmıştır.

\section{İndeks Özellikler ve Doğa Kaynaklı Riskler}

Mühendislik jeolojisi haritaları hazırlanırken, jeoteknik-mühendislik verilerinin üretilmesi, proje özelinde ve projenin doğasına uygun testlerin yapılmasını gerektirmektedir. Erzincan yöresinde ve aynı kuşakta yer alan tüm jeolojik birimlerin jeoteknik-mühendislik özellikleri, yüksek, orta ve düşük değerleri tanımlanmıştır (Aktimur vd., 1988).

Çevre jeolojisi haritaları için ise öncelikle çevresel sistemlerin ve çevresel birimlerin tanımlanması ve jeolojik birimlerin çevresel bir sistem içinde yer alan çevresel birimlere dönüştürülmesi gerekmektedir. Sunulan çevresel sistemlerle, çevresel birimlerde yer alan kaya türlerinin bazı indeks özellikleri de Kayseri yöresinde Kılıçdağ1 vd. (1999), Sivas yöresinde Avc1 vd. (1997a ve b) tarafından incelenmiştir. Bu çalışmalarda, tüm birimlerin Sonik hız değerleri, tek nokta yükleme değerleri, elastik deformasyon modülü, tek eksenli sıkıştırma dayanımı, tanjant young modülü gibi özellikleri tanımlanmıştır. Öte yandan ISRM (1981), Ulusay’1n (2010) ve Yılmaz'ın (2009) arazi gözlemleri için önerdikleri hususlar da değerlendirilmiştir. 
Boz, Yılmaz

Çizelge 2. Çevresel sistemlerde yer alan çevresel birimlerin genel özellikleri.

Table 2. General characteristic features of the environmental units in the environmental systems.

\begin{tabular}{|c|c|c|c|c|c|c|}
\hline & Birimler & 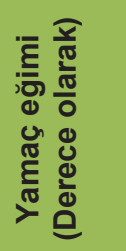 & 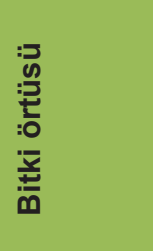 & 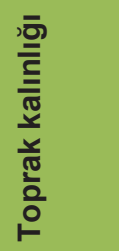 & 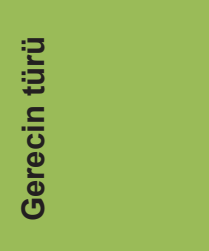 & 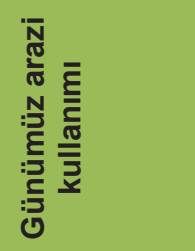 \\
\hline \multirow{10}{*}{ 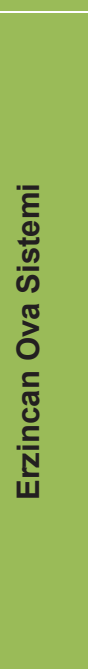 } & Genç volkanitler & $0-20$ & $\begin{array}{l}\text { Seyrek } \\
\text { çeşitli } \\
\text { ağaçlar }\end{array}$ & İnce & $\begin{array}{l}\text { Andezit, } \\
\text { bazalt, dasit }\end{array}$ & $\begin{array}{c}\text { Ocak } \\
\text { işletmesi }\end{array}$ \\
\hline & Traverten & $0-10$ & $\begin{array}{l}\text { Otsu } \\
\text { bitkiler }\end{array}$ & - & $\begin{array}{c}\text { Karbonatik } \\
\text { kayatürü }\end{array}$ & $\begin{array}{c}\text { Ocak } \\
\text { işletmesi }\end{array}$ \\
\hline & Havza dolgusu & - & - & - & - & - \\
\hline & - İri taneli & $0-5$ & $\begin{array}{l}\text { Otsu } \\
\text { bitkiler }\end{array}$ & Orta & Çakıltaşı & Mera, tarım \\
\hline & $\begin{array}{l}\text {-Orta } \\
\text {-ince taneli }\end{array}$ & $0-2$ & Ekin & Kalın & $\begin{array}{c}\text { Kumtaşı } \\
\text { kiltaşı }\end{array}$ & $\begin{array}{l}\text { Mera, tarım } \\
\text { Tarım }\end{array}$ \\
\hline & $\begin{array}{l}\text { Alüvyon } \\
\text { yelpazeleri }\end{array}$ & $0-5$ & Çimen & Kalın & Irit ince taneli & Mera \\
\hline & Sazlıklar & $0-3$ & Sazlık & Kalın & Kum, kil, silt & Dinlenme \\
\hline & Kaynaklar & - & Kavak & - & - & Sulama \\
\hline & Akarsular & $0-05$ & " & - & - & Sulama \\
\hline & Taşkın alanı & $0-10$ & $\begin{array}{l}\text { Seyrek } \\
\text { çeşitli } \\
\text { ağaçlar }\end{array}$ & Orta & $\begin{array}{l}\text { Yelpaze } \\
\text { çökelleri }\end{array}$ & Mera \\
\hline \multirow{9}{*}{ 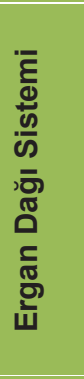 } & $\begin{array}{l}\text { Metamorfik } \\
\text { kayalar }\end{array}$ & $10-45$ & " & İnce & $\begin{array}{l}\text { Şist, gnays, } \\
\text { metavolkanit }\end{array}$ & $\begin{array}{l}\text { Dinlenme, } \\
\text { avcllık }\end{array}$ \\
\hline & Masif kireçtaşı & $10-45$ & $"$ & İnce & Kireçtaşı & " \\
\hline & Resifal kireçtaşı & $0-30$ & $"$ & İnce & " & $"$ \\
\hline & Pelajik kireçtaşı & $0-20$ & $"$ & Orta & " & $"$ \\
\hline & Ofiyolitler & $0-35$ & $"$ & İnce & Peridodit & " \\
\hline & Ofiyolitli karışık & $0-30$ & $"$ & İnce & Çeşitli & $"$ \\
\hline & Kırıntılı kayalar & $0-45$ & $"$ & Orta & Kayatürleri & $"$ \\
\hline & Volkanitler & $0-35$ & $"$ & " & Andezit & $"$ \\
\hline & Evaporitler & $0-25$ & " & " & Jips & " \\
\hline \multirow{9}{*}{ 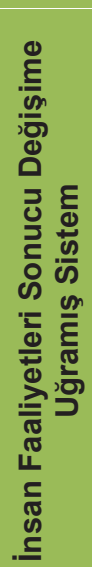 } & $\begin{array}{l}\text { Tarım yapılan } \\
\text { yerler }\end{array}$ & $0-05$ & Ekili alan & Kalın & Toprak & $\begin{array}{l}\text { Çiftçilik, } \\
\text { tarım }\end{array}$ \\
\hline & $\begin{array}{l}\text { Taş ve maden } \\
\text { ocakları }\end{array}$ & - & - & İnce & - & $\begin{array}{c}\text { Ocak } \\
\text { işletmesi }\end{array}$ \\
\hline & Deponi alanları & $0-02$ & $\begin{array}{c}\text { Otsu } \\
\text { bitkiler }\end{array}$ & - & Alüvyon & $\begin{array}{l}\text { Çöp } \\
\text { depolama } \\
\text { yeri }\end{array}$ \\
\hline & Baraj ve göletler & - & Yeşilalan & Orta & - & HES,Sulama \\
\hline & Karayolları & - & - & - & - & Ulaşım \\
\hline & Demiryolları & - & - & - & - & Ulaşım \\
\hline & Dinlenme yerleri & - & $\begin{array}{l}\text { Çeşitli } \\
\text { ağaçlar }\end{array}$ & - & - & Dinlenme \\
\hline & Ormanlar & - & & $\begin{array}{l}\text { Kalın- } \\
\text { Orta }\end{array}$ & - & $\begin{array}{c}\text { Turizm } \\
\text { Konaklama }\end{array}$ \\
\hline & Yerleşim yerleri & - & $"$ & " & Çeşitli & Turizm \\
\hline
\end{tabular}



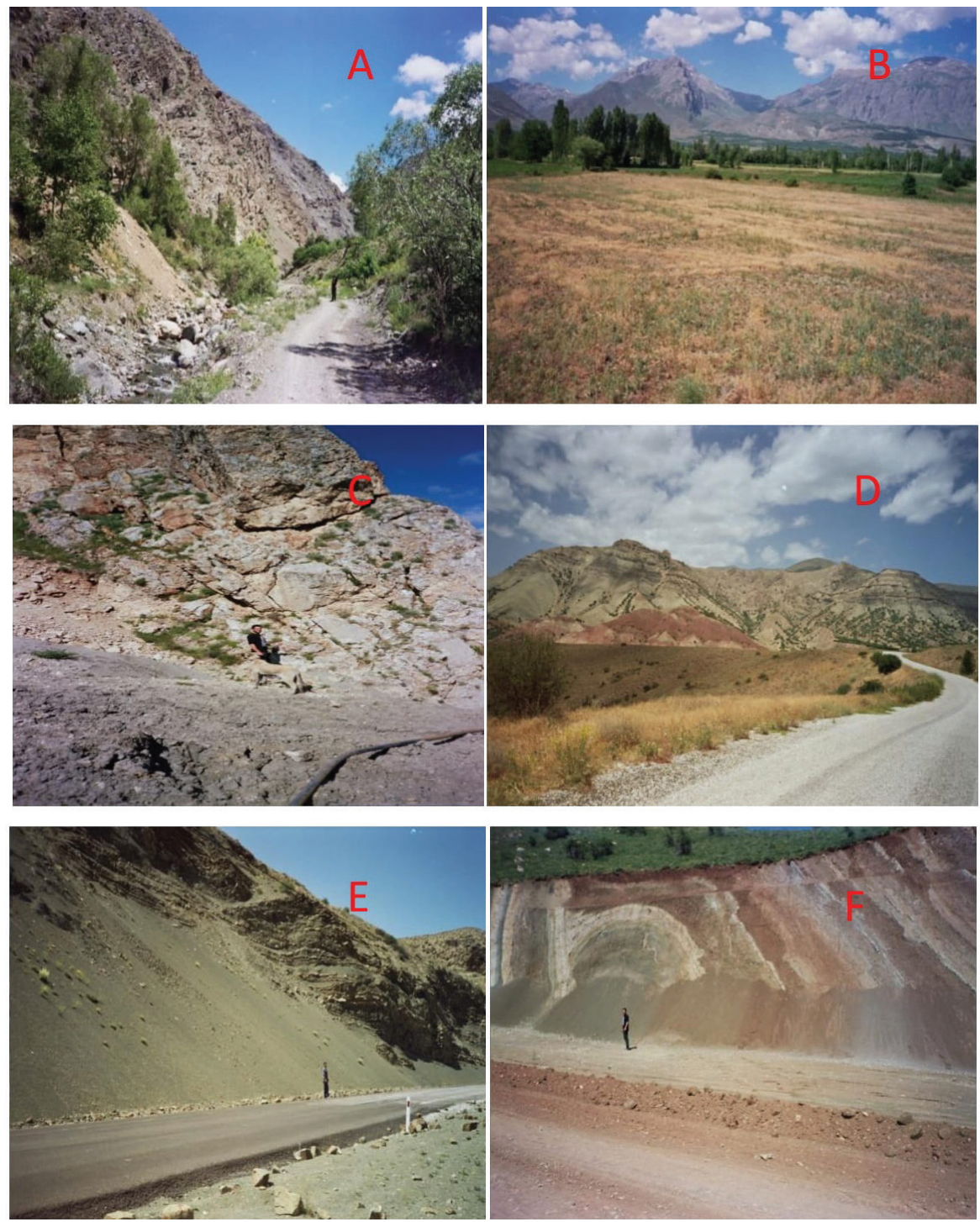

Şekil 10. Ergan Dağı Sistemi’nin birimlerinden bazı görüntüler (A, Üzümlü ilçesi kuzeyi metamorfik kayalar (metavolkano-tortul dizi); B, Yalınca köyünden Mercan dağına bakış, Munzur kireçtaşı ve üzerinde tektonik bir dokanakla yer alan ofiyolitler (Serpantinleşmiş peridodit); C, Çilhoruz batısı, Jura-Alt Kretase yaşta katmanlı kireçtaşı; D, Sürekköy dolayı, Oligo-Miyosen yaşta morumsu çakıltaşı altta, gri orta-ince taneli kıvrımlı kayatürleri üstte; E, Sürekköy dolayı, Oligo-Miyosen yaşta orta-ince taneli kırıntılı kayaların yakından görünümü; F, Gözedağ1 yöresi, Mecidiye köyü Oligo-Miyosen yaşta kırıntılı karasal istif .

Figure 10. Views from environmental units in the Ergandağ System. (A, Metamorphic rocks (metavolcanosedimentary sequence) to the north of Üzümlü district); B, A view from Munzur limestone and obducted ophiolites (serpentinized peridodite)along the Mercan Mountain near Yaltnca village; C, Jurassic-Lower Cretaceous layered limestone, to the west of Çilhoruz village; D, Purplish conglomerate in Oligo-Miocene age in the lower level, gray medium-fine-grained folded rock types in the upper level, to the west of Çilhoruz; E, A close view from mediumfine-grained clastic rocks of Oligo-Miocene age, around Sürekköy; F, Oligo-Miocene clastic continental sequence, around Mecidiye village, in the Gözedă̆l region. 
Boz, Yılmaz
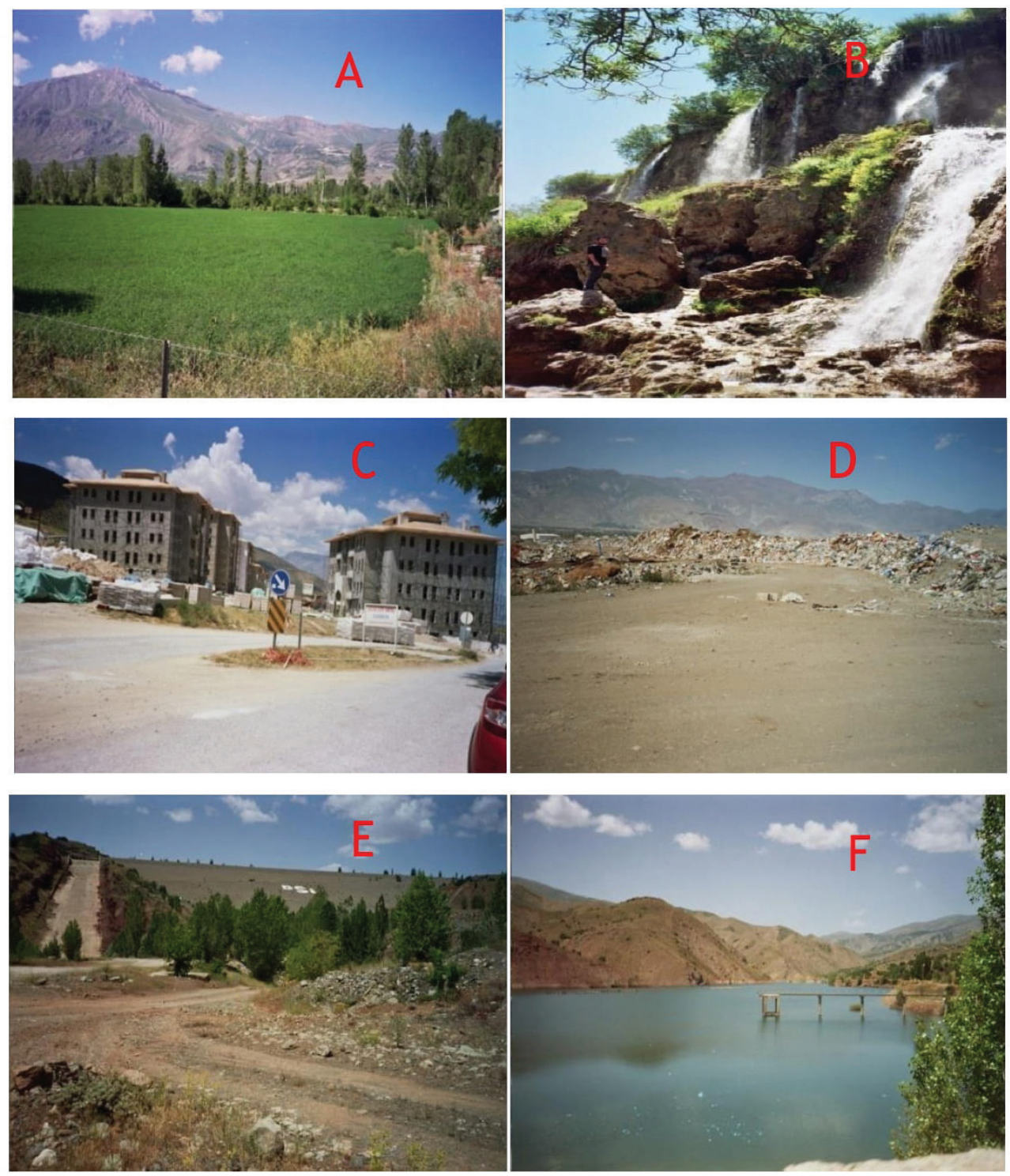

Şekil 11. İnsan Eliyle Değişime Uğramış (Antropojenik) Sistem'in bazı birimlerine ait görüntüler (A, Yalınca köyünden güneye bakış, Ova'da tarım yapılan alan); B, Girlevik köyü dolayı, dinlenme amaçlı duyarlı alanlar kapsamında yer alan Girlevik Şelalesi'nin yakından görünümü; C, Girlevik köyü girişi yapılan ve yapılmakta olan TOKİ inşaatında bir görüntü; D, Çatalören köyü kuzeyi, Erzincan deponi alanından genel bir görüntü; E, Erzincan Çatalarmut baraj gövdesi ve dolu-savakın görünümü ile yakın dolayındaki atıklar; F, Erzincan Çatalarmut barajının göl alanı.

Figure 11. Views from Environmental Units in the Antropogenical System. (A, A view from Yalinca village to the the south, an agricultural area in the Plain); B, A close view from the Girlevik waterfall, which is located within the scope of sensitive recreation areas, around Girlevik village; $C$, A view from TOKI construction area, in the entry of the Girlevik village, where still being construction; D, A general view from the Erzincan landfill, to the north of Çatalören village; E, Viewsfrom the Erzincan Çatalarmut dam body and spillway and also wastes in its immediate vicinity; F, Reservoir area of the Erzincan Çatalarmut dam. 
Çizelge 3. Çevresel sistemler ve bu sistemlerde yer alan çevresel birimlerin jeoteknik- mühendislik özellikleri ve etkin olan doğa kaynaklı yer süreçleri.

Table 3. Geotechnical-engineering properties of the environmental units in the Environmental systems and active natural earth processes.

\begin{tabular}{|c|c|c|c|c|c|c|c|c|c|c|}
\hline$\frac{\frac{d}{E}}{\frac{\Phi}{\omega}}$ & Birimler & 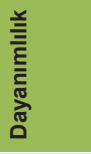 & 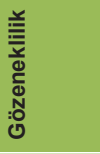 & 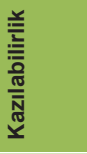 & 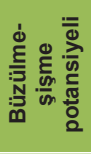 & 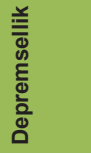 & $\frac{\frac{5}{\pi}}{\frac{0}{0}}$ & 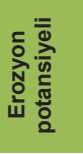 & 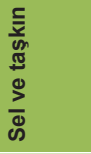 & 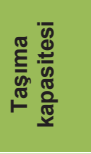 \\
\hline \multirow{10}{*}{ 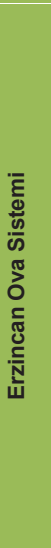 } & Genç volkanitler & Orta & Düşük & Orta & Düşük & Yüksek & Düşük & Düşük & Düşük & Orta \\
\hline & Traverten & Orta & Orta & Düşük & $"$ & Düşük & $"$ & $"$ & $"$ & $"$ \\
\hline & Havza dolgusu & - & - & - & - & - & - & - & - & - \\
\hline & - İri taneli & Orta & Yüksek & Orta & Düşük & Orta & Orta & Orta & Orta & Orta \\
\hline & $\begin{array}{l}\text { - Orta } \\
\text { - İnce taneli }\end{array}$ & $\begin{array}{l}\text { Orta } \\
\text { Düşük }\end{array}$ & $\begin{array}{l}\text { Orta } \\
\text { Düşük }\end{array}$ & $"$ & $\begin{array}{c}\text { Orta } \\
\text { Yüksek }\end{array}$ & " & $\begin{array}{c}\text { " } \\
\text { Yüksek }\end{array}$ & Yüksek & Yüksek & Düşük \\
\hline & Alüvyon yelpazeleri & $"$ & Yüksek & $"$ & Düşük & " & Orta & Orta & Yüksek & $"$ \\
\hline & Sazlıklar & - & - & - & - & - & Düşük & Düşük & $"$ & $"$ \\
\hline & Kaynaklar & - & - & - & - & - & - & - & - & - \\
\hline & Akarsular & - & - & - & - & - & - & - & - & - \\
\hline & Taşkın alanı & - & Orta & Yüksek & - & - & Yüksek & Yüksek & Yüksek & Düşük \\
\hline \multirow{9}{*}{ 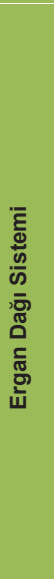 } & Metamorfik kayalar & Yüksek & Düşük & Düşük & Düşük & Düşük & Düşük & Düşük & Düşük & Yüksek \\
\hline & Massif kireçtaşı & $"$ & $"$ & $"$ & " & " & Orta & Orta & $"$ & $"$ \\
\hline & Katmanlı kireçtaşı & $"$ & $"$ & $"$ & $"$ & $"$ & $"$ & $"$ & $"$ & $"$ \\
\hline & Pelajik kireçtaşı & $"$ & $"$ & $"$ & $"$ & $"$ & $"$ & $"$ & $"$ & $"$ \\
\hline & Ofiyolitler & Orta & Düşük & $"$ & $"$ & $"$ & $"$ & $"$ & $"$ & $"$ \\
\hline & Ofiyolitli karışık & Orta & Orta & Orta & $"$ & Orta & Düşük & Düşük & Düşük & Orta \\
\hline & Kırıntılı kayalar & Düşük & $"$ & $"$ & Yüksek & " & Orta & Orta & Orta & $"$ \\
\hline & Volkanitler & Yüksek & $"$ & Düşük & Düşük & $"$ & Düşük & Düşük & Düşük & Yüksek \\
\hline & Jipsli dizi & Düşük & Orta & Orta & Yüksek & Yüksek & Yüksek & Yüksek & Orta & Düşük \\
\hline \multirow{9}{*}{ 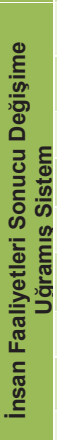 } & Tarım yapılan yerler & $"$ & Orta & Yüksek & Orta & Orta & Düşük & Orta & $"$ & Orta \\
\hline & Taş ve maden ocakları & - & Orta & - & Orta & $"$ & - & - & $"$ & - \\
\hline & Deponi alanları & - & - & - & Yüksek & - & - & - & - & Düşük \\
\hline & Baraj ve göletler & Düşük & Orta & Orta & - & Yüksek & Yüksek & Düşük & Yüksek & $"$ \\
\hline & Demiryolları & - & - & - & - & - & - & - & Orta & - \\
\hline & Karayolları & - & - & - & - & - & - & - & Orta & - \\
\hline & Dinlenme yerleri & - & - & - & - & - & - & - & - & - \\
\hline & Ormanlar & - & - & - & - & - & - & - & - & - \\
\hline & Yerleşim yerleri & - & - & - & - & - & - & - & Orta & - \\
\hline
\end{tabular}


Boz, Yılmaz

Çizelge 4. Erzincan Ovası ve dolayındaki çevresel sistemlerin ve ilgili birimlerin arazi yetenek değerlendirme matrisi.

Table 4. Land-use capability matrix of the environmental systems of the Erzincan Plain and surroundings.

\begin{tabular}{|c|c|c|c|c|c|c|c|c|c|c|c|}
\hline$\frac{\frac{\bar{\omega}}{E}}{\frac{\bar{\Phi}}{\omega}}$ & $\begin{array}{c}\text { Faaliyetler }> \\
\text { Birimler } \\
\end{array}$ & 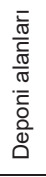 & 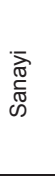 & 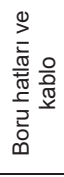 & 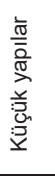 & $\begin{array}{l}\frac{\bar{\sigma}}{\overline{0}} \\
\frac{0}{0} \\
\frac{1}{2} \\
: \frac{7}{0} \\
: \frac{3}{0}\end{array}$ & 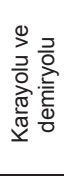 & 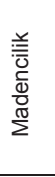 & 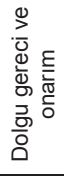 & $\stackrel{\varepsilon}{\frac{\varepsilon}{\leftrightarrows}}$ & 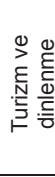 \\
\hline \multirow{10}{*}{ 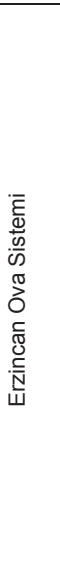 } & Genç volkanitler & $\square$ & $\square$ & 0 & $x$ & $\square$ & $\square$ & $x$ & $x$ & $\Delta$ & $x$ \\
\hline & Traverten & $\square$ & $\square$ & $\square$ & $\Delta$ & $\square$ & $\square$ & $\mathbf{x}$ & $x$ & $\Delta$ & $x$ \\
\hline & Havza dolgusu & $\square$ & $(-)$ & $(-)$ & $(-)$ & $(-)$ & $(-)$ & $(-)$ & $(-)$ & $(-)$ & $(-)$ \\
\hline & - İri taneli & $\square$ & $\Delta$ & $(-)$ & $(-)$ & $(-)$ & $(-)$ & $(-)$ & $(-)$ & $\mathrm{x}$ & $\Delta$ \\
\hline & $\begin{array}{l}\text { - Orta } \\
\text { - Ince taneli }\end{array}$ & $\vec{x}$ & $\begin{array}{l}\Delta \\
\Delta\end{array}$ & $\begin{array}{l}\square \\
\square\end{array}$ & $\begin{array}{l}\mathbf{X} \\
\mathbf{X}\end{array}$ & $\begin{array}{l}\square \\
\square\end{array}$ & $\begin{array}{l}\text { ㅁ } \\
\square\end{array}$ & $\begin{array}{l}\square \\
\square\end{array}$ & $\begin{array}{l}X \\
X\end{array}$ & $\begin{array}{l}\mathbf{X} \\
\mathbf{X}\end{array}$ & $\begin{array}{l}X \\
X\end{array}$ \\
\hline & Alüvyon yelpazeleri & $\square$ & $\Delta$ & $\square$ & $\Delta$ & $\square$ & $\square$ & $\square$ & $x$ & $\mathbf{x}$ & $x$ \\
\hline & Sazlıklar & $\square$ & $\Delta$ & $\square$ & $\Delta$ & $\square$ & ㅁ & $\square$ & $\square$ & ㅁ & $x$ \\
\hline & Kaynaklar & $\square$ & $\Delta$ & $(-)$ & $(-)$ & $(-)$ & $(-)$ & $(-)$ & $(-)$ & $(-)$ & $\mathrm{x}$ \\
\hline & Akarsular & $\square$ & $\Delta$ & $(-)$ & $(-)$ & $(-)$ & $(-)$ & $(-)$ & $(-)$ & $(-)$ & $\mathrm{x}$ \\
\hline & Taşkın alanı & 口 & $\Delta$ & $\square$ & 口 & 口 & 口 & 口 & 口 & $(-)$ & $\Delta$ \\
\hline \multirow{9}{*}{ 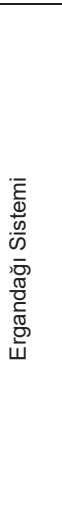 } & Metamorfik kayalar & $\square$ & $x$ & 0 & $\mathrm{x}$ & 0 & $\mathrm{x}$ & $\mathrm{x}$ & $\mathrm{x}$ & ㅁ & $\mathrm{x}$ \\
\hline & Massif kireçtaşı & $\square$ & $x$ & 0 & $x$ & 0 & $\mathrm{x}$ & $x$ & $\mathrm{x}$ & $x$ & $x$ \\
\hline & Katmanlı kireçtaşı & $\square$ & $x$ & o & $\mathrm{x}$ & o & $\mathrm{x}$ & $x$ & $x$ & $x$ & $x$ \\
\hline & Pelajik kireçtaşı & $\square$ & $x$ & 0 & $\mathrm{x}$ & 0 & $\mathbf{x}$ & $x$ & $x$ & $x$ & $x$ \\
\hline & Ofiyolitler & $\square$ & $\square$ & $x$ & $\mathrm{x}$ & $x$ & $\mathbf{x}$ & $x$ & $\mathbf{x}$ & $\Delta$ & $\Delta$ \\
\hline & Ofiyolitli karışık & $\square$ & $\square$ & $x$ & $\mathrm{x}$ & $x$ & $\mathrm{x}$ & $x$ & $x$ & $\Delta$ & $\Delta$ \\
\hline & Kırıntılı kayalar & $\square$ & $\square$ & 0 & $\Delta$ & $x$ & $x$ & $x$ & $x$ & $x$ & $x$ \\
\hline & Volkanitler & $\square$ & $x$ & 0 & $\mathrm{x}$ & 0 & $x$ & $x$ & $\mathrm{x}$ & $\square$ & $x$ \\
\hline & Jipsli dizi & $\square$ & 0 & 0 & 0 & o & o & 0 & 口 & $\square$ & $\square$ \\
\hline \multirow{9}{*}{ 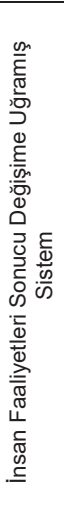 } & Tarım yapılan yerler & $\square$ & $\Delta$ & $\square$ & $\mathrm{x}$ & $\square$ & $\square$ & $\square$ & $\Delta$ & $\mathrm{x}$ & $\square$ \\
\hline & Taş ve maden ocakları & $\square$ & $x$ & $\square$ & $\square$ & $\square$ & $\square$ & $x$ & $x$ & $\Delta$ & $\square$ \\
\hline & Deponi alanları & $(-)$ & $\square$ & $\square$ & $\square$ & $\square$ & $\square$ & $\square$ & $\square$ & $\Delta$ & $\square$ \\
\hline & Baraj ve göletler & $\square$ & $\square$ & $\square$ & $x$ & $\square$ & $\square$ & $\square$ & $x$ & $\mathrm{x}$ & $x$ \\
\hline & Demiryolları & $\square$ & $(-)$ & $(-)$ & $(-)$ & $(-)$ & $(-)$ & $x$ & $(-)$ & $(-)$ & $(-)$ \\
\hline & Karayolları & $\square$ & $(-)$ & $(-)$ & $(-)$ & $(-)$ & $(-)$ & $\square$ & $(-)$ & $(-)$ & $(-)$ \\
\hline & Dinlenme yerleri & $\square$ & $\Delta$ & $(-)$ & $(-)$ & $(-)$ & $(-)$ & $(-)$ & $(-)$ & $\Delta$ & $\mathbf{x}$ \\
\hline & Ormanlar & $\square$ & $\Delta$ & $(-)$ & $(-)$ & $(-)$ & $(-)$ & $(-)$ & $(-)$ & $\Delta$ & $x$ \\
\hline & Yerleşim yerleri & 口 & $\square$ & $(-)$ & $(-)$ & $(-)$ & $(-)$ & $(-)$ & $(-)$ & $(-)$ & $(-)$ \\
\hline
\end{tabular}


Çizelge 4'de çevresel açıdan sorunlu birimler için $\square$, doğa kaynaklı riskler açısından sorunlu birimler için $\mathrm{O}$, faaliyetlerin türü için uygun olmayan birimler için $\Delta$, faaliyetlerin türü için uygun yerler için $X$ ve değerlendirme yapılamayan birimler için de (-) sembolleri kullanılmıştır. Sunulan bu değerlendirme, İnsan Faaliyetleri Sonucu Değişime Uğramış Sistem'de yer alan faaliyetlerle, değerlendirmeye alınan faaliyetler örtüşmekte olduğu durumlar için de geçerlidir.

Ayrıntılı testlerin değerlendirildiği mühendislik jeolojisi haritalarında, mühendislik ya da indeks özelliklerin sinıflandırılmasında genel olarak en düşük, düşük, orta, yüksek, en yüksek karşılığı bir sınıflama kullanılmaktadır. Ancak, bölgesel çevre jeolojisi haritalarında, daha geniş alanlara dair yorumlama gereksinimi için, söz konusu değerlerinin kullanımında, olabildiğince risk oranını azaltmak için düşük, orta ve yüksek gibi değerlerin kullanılması tercih edilmektedir. Buna göre, örneğin dayanımlılık için $\mathrm{MPa}\left(10 \mathrm{kgf} / \mathrm{cm}^{2}\right)$ yaklaşık olarak 30'dan küçük ise düşük, 30-110 aras1 orta, 110'dan büyük ise yüksek olarak kabul edilmiştir. Aynı şekilde gözeneklilik için indeks değeri \%30'dan fazla ise yüksek, $\% 5-30$ arası orta, $\% 5$ 'den az ise düşük değerler; büzülme-şişme için ise $\% 35$ 'den büyük ise yüksek, $\% 20-35$ ise orta, $\% 20$ 'den az ise düşük karş1lığ 1 değerler kullanılmıştır. Diğer değerlendirmeler için de benzer bir yöntem izlenmiştir. Ancak, herhangi bir tesisin ayrıntılı yer seçimi özelinde yapılacak değerlendirmede, mutlaka yere özgü testlerin yapılması ve mühendislik jeolojisi haritalarında öngörülen sinıflamaların kullanılması tercih edilmelidir.

Boz (2015), yukarıda sunulan kaynaklarda yer alan verileri, yapılan saha çalışmasındaki gözlemleriyle birleştirerek Erzincan ovası ve yakın dolayı için tanımlanan çevresel sistemlerin birimlerine uyarlamıştır. Çizelge 3'de Erzincan ovası ve yakın dolayında ayırt edilen çevresel birimlerin bazı jeoteknik özellikleri ve bölgede etkin olan doğa kaynaklı riskler açısından yapılan değerlendirme görülmektedir.

\section{Çevresel Sistemlerin Arazi Yetenek Değerlendirmesi}

Erzincan ovası ve dolayını temsil eden çevresel birimlerin indeks özellikleri ve yerel doğa kaynaklı riskler de gözetilerek çevresel birimlerin çeşitli arazi kullanım biçimleri açısından değerlendirilmesinde yarar vardır. Aktimur vd. (1988) tarafindan incelenen jeoteknik - mühendislik özelliklerinin yerliyerinde (in-situ) geçerli olduğunu göz ard1 etmeden, bu testlerde varılan sonuçları arazi gözlemleriyle birleştirilerek çevresel birimlerin durumunu değerlendirmiştir. Değerlendirmede yukarıda yapılan açıklama 1şı̆̆ında Düşük, Orta ve Yüksek değerleri kullanılmıştır. Değerlendirme yapılamayan birimler için işareti kullanılmıştır. Bu değerlendirme çevresel sistemleri içeren birimlerin ön arazi kullanımı açısından uygunluğu test edilmiştir. Sunulan arazi yetenek değerlendirme matrisi Çizelge 4'de görülmektedir. Bu matris çevresel açıdan sorunlu yerleri, doğa kaynaklı afetler açısından riskli yerleri ayırdığı gibi, her faaliyet için uygun olan ya da uygun olmayan yerleri ve değerlendirmenin yapılamadığı alanları da göstermektedir.

Sunulan çalışmada, jeolojik birimler, önce çevresel birimlere dönüştürülmüştür. Bunun için jeolojik birimlerin birbirine yakın jeoteknikmühendislik değerleri gözetilerek, bu birimler, aynı çevresel birim adı altında birleştirilmiştir. Buna göre, örneğin, Miyosen yaşta olan kırıntılı kayalar ile Jura yaşta olan kırıntılı kayalar, aynı değerlere sahip olmasa bile birbirine yakın değerlere sahip olmaları nedeniyle, aynı çevresel birimi temsil etmektedir. 
Çevre jeolojisi haritalarından azami ölçüde yararlanabilmek için, üretilen haritaların ve oluşturulan matrislerin birlikte değerlendirilmesi gerekmektedir. Şekil 8'de tanımlanan çevresel birimler; bu birimlerin doğa kaynaklı riskler açısından değerlendirmeleri de Çizelge 3'de sunulan matriste görülmektedir. Örneğin, Çizelge 3'de Ergan Dağı Sistemi'nde yer alan metamorfik kayalar biriminde heyelan riski düşük, kırıntılı kayalarda ise orta düzeydedir. Şekil 8'de ise bu çevresel birimlerin yayılımı yer almaktadır. Belirlenen heyelanların ve doğa kaynaklı diğer risklerin yerel konumları ise Şekil 4'de sunulmuştur.

Çizelge 4'de ise çevresel birimlerin çeşitli faaliyetler açısından değerlendirilmesini yansıtan bir matris sunulmuştur. $\mathrm{Bu}$ matris ise, çevresel sistemlerin tanımlanan birimleriyle arazi kullanım biçimleri arasındaki ilişkiler irdelenmiştir. Örneğin, Erzincan Ova Sisteminde volkanitler birimi madencilik; havza dolgusunu temsil eden iri, orta ve ince taneli kırıntılı birim ise tarım açısından bir potansiyel taşımakta olup $\mathbf{X}$ ile temsil edilmektedir. Bu birimlerin yayılımı ise Şekil 8'de görülmektedir. Arazi kullanım potansiyel haritası ise özel olarak Şekil 6' da sunulmuştur.

\section{ERZINCAN OVASI VE DOLAYININ GELECEĞE YÖNELİK BÖLGESEL PLANLAMASI}

Erzincan Ovası ve yakın dolayını içine alan bölgenin mevcut durumuna bakıldığında, bölgenin kayda değer doğal kaynaklara sahip olduğu, ancak doğa kaynaklı risklerin de tehdidi altında olduğu açıkça görülür. Böyle bir bölgede geleceğe yönelik bir planlama yapmanın güçlükleri göz ardı edilemez. Aşağıda, yörenin tüm çevresel özellikleri gözetilerek sadece bazı hususların dikkate alınmasında yarar görülmektedir. Söz konusu hususlar, Şekil 12'de sunulmuştur.

Erzincan Ovası'nı bir bütün olarak kuşatan ve ulaşım açısından büyük kolaylıklar sağlayan raylı bir sistem öncelikli bir öneridir. Genel olarak güzergâhı izlenen raylı sistem (yani yeni bir demiryolu) ile Ova'nın çevresindeki köylerin kendi arasında ve bu köylerin kent merkeziyle ulaşımını sağlarken, günümüzde çeşitli vasıtalarla yapılan ulaşım şekline de son verecektir. Böyle bir uygulama, tarım arazilerinin korunmasına ve fosil yakıtlar nedeniyle oluşan hava kirliliğinin önlenmesine katkı sağlayacaktır. Halk istediği yere ulaşma hususunda bir sıkıntı yaşamayacağ 1 gibi, tarlalarında tarım yaparken, çalışacağı yerlere yakın yeni evlere de ihtiyaç duymayacaktır.

Erzincan Ovası, yapılan tüm değerlendirmelere göre sel ve taşkın tehdidi altındadır. 50 ya da 100 yılda bir gelmesi olası sel ve taşkınların ovanın büyük bir bölümünü etkilemesi muhtemeldir. Dolayısıyla, Yukarı Firat nehrinin Ova'ya kavuşan kollarının kenar kısımlarına kapsamlı bir şekilde setler yapılarak bölgedeki yerleşim yerlerinin ve tarım alanlarının sel ve taşkın tehlikesinin denetimi önemli ölçüde kontrol altına alınabilir.

Erzincan ilinde korunması gereken iki önemli alan vardır. Bu alanlardan ilki Girlevik Şelalesi, diğeri de Ekşisu Sazlığı'dır (Şekil 8). Bu alanların hem sel ve taşkın açısından yüksek risk (Çizelge 3; Erzincan Ova Sistemi, Sazlıklar Birimi), hem de insan faaliyetlerinin tehdidi altında olduğu ve mutlaka korunma altına alınmaları gerekmektedir. Aksi takdirde her iki alan yok olma tehlikesiyle karşı karşıya kalacaktır. 


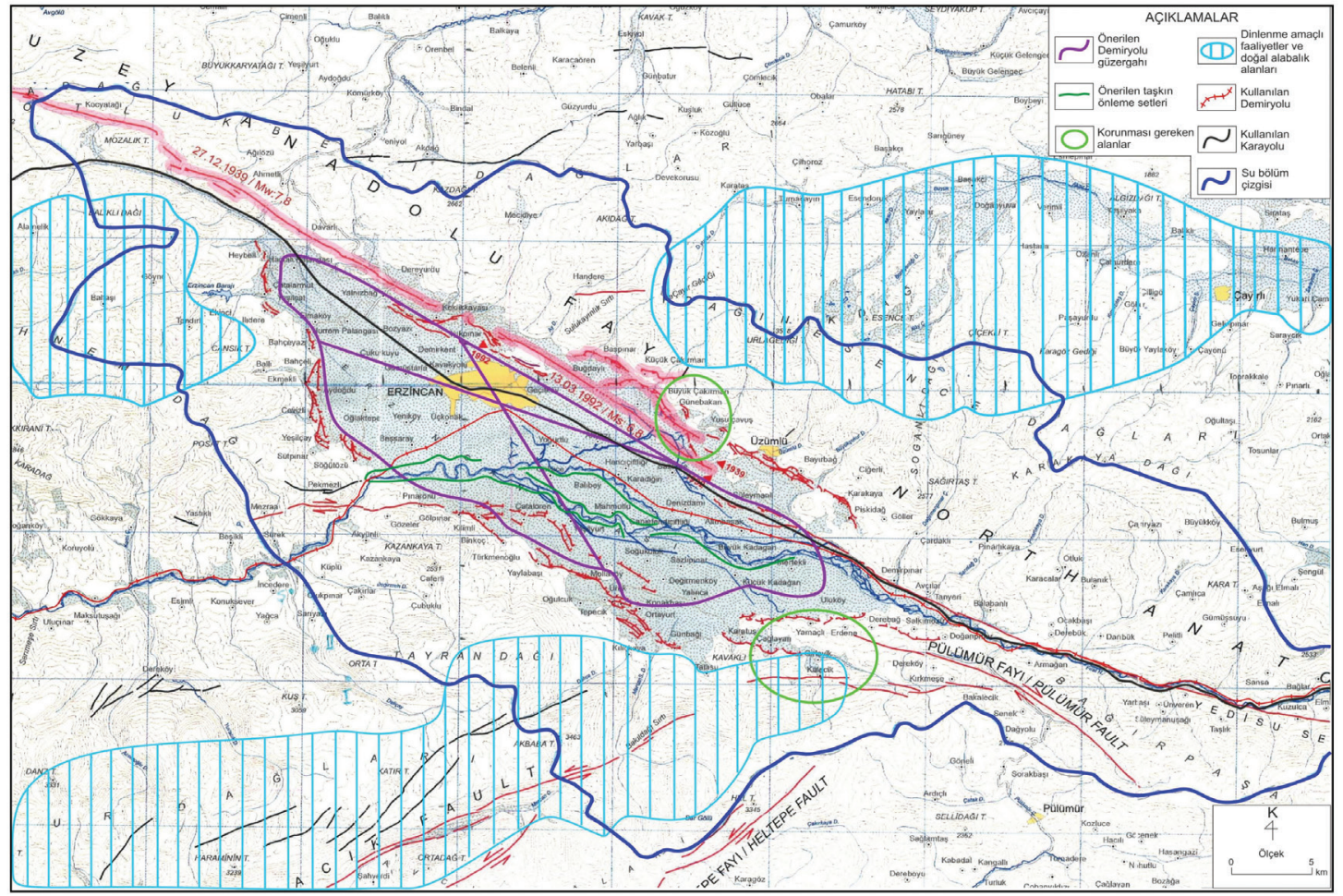

Şekil 12. Erzincan Ovası ve dolayının yeniden planlanmasında gözetilmesi gereken yeni öneriler.

Figure 12. Some suggestions for new planning of the Erzincan Plain and surroundings.

Girlevik Şelalesi, Ova'nın güneydoğusunda, Munzur dağları'nın Ova'ya kavuştuğu yerde bulunmaktadır. Munzur Kireçtaşları, şelaleyi oluşturan akarsuların akiferi durumundadır. Ancak bölge halen TOKİ'nin gözetiminde yerleşime açılmış durumdadır. Şelaleye oldukça yakın yerlerde konutların yapımı devam etmektedir. Bu konutların su gereksinimi elbette ya bölgenin yer altı sularından ya da şelaleyi oluşturan sulardan karşılanacaktır. Her iki durumda konutların gereksinimi karşılanırken Şelalenin gelişimi ve seyri etkilenecektir. Dolayısıyla bu bölgede geleceğe yönelik bazı sinırlamaların getirilmesi zorunludur. Bu bölgede su miktarı azalmış olup buna bağlı olarak traverten oluşumu daha önceki dönemlere göre daha yavaştır. Bunun bir nedeni de meteorolojik koşullar da olabilir.
Ekşisu Sazlığı ise Ova'nın kuzeyinde ve Üzümlü ilçesinin batısında yer almaktadır. $\mathrm{Bu}$ bölge aynı zamanda termal amaçla değerlendirilmektedir. Kuzey Anadolu Fay1 boyunca oldukça genç volkanitler yer almaktadır. $\mathrm{Bu}$ volkanitler olasılıkla bu termal kaynağın 1sitıcıs1 durumundadır. Yani, bu termal kaynak doğal olarak uzun süre etkinliğini koruyacaktır. Böyle bir durumda Ekşisu Sazlığı'nın uzun ve verimli bir planlamaya gereksinimi vardır. Bölgenin yeniden elden geçirilmesi ve daha etkin bir çekim merkezi haline getirilmesi mümkündür. Bunun için öncelikle Ekşisu Sazlığı'nın yasal bir güvenceye kavuşturulması gerekmektedir.

Ayrıca, Ezincan Ovası'nın kuzeydoğusunda Esence Dağı, güneyinde ve güneybatısında Munzur Dağları ve Ergan Dağı ile batısında 
Köhnem Dağı oldukça yüksek ve dağ turizminin yapılabileceği önemli yerlerdir. Bu bölgeler, kar yağışının yoğun olduğu kış dönemlerinde kayak merkezlerini inşa ederek değerlendirilebilir. Esence dağlarının kuzey yamaçlarında ve yüksek yerlerde Temmuz ayında da kar eksik olmaz. Ayrıca bu yüksek alanlardan Firat nehrine akan tertemiz akarsularda doğal alabalığın yanı sıra bölgeye özgü çeşitli sazan balık türleri de yaşamaktadır. Dolayısıyla bu alanlar, dinlenme amaçlı ve olta ile alabalık avcılığı için uygun alanlardir.

\section{SONUÇLAR VE ÖNERİLER}

$\mathrm{Bu}$ bölgede pek çok çalışma yapılmış ve bu çalışmalar bölgenin anlaşılmasına katkıda bulunmuştur. Çalışma alanının 1/50.000 ölçekli jeolojik ve mühendislik jeolojisi, mühendislik özellikleri bakımından toprak sınıflaması ve hafriyat koşulları tanımlanmıştır. Ayrıca uygulamalı jeomorfoloji, uygulamalı eğim haritaları, hidrojeoloji, su kaynakları, sismik risk, toprak ve arazi kullanım potansiyeli haritalarına dair çeşitli çalışmalar yapılmıştır (DSİ, 1981, 2010; Aktimur vd., 1988, MTA, 2003, 2012a; Boz, 2015).

Bu çalışmalar sonucunda yöreye dair mevcut durum tanımlanmıştır. Bu çerçevede Erzincan Ovasındaki çevresel sorunları iki gruba ayırt ederek irdelemekte yarar vardır.

Birinci grupta yer alan sorunlar doğa kaynaklı risklerdir. Bu riskler, özellikle deprem, heyelan, çı̆̆, sel ve taşkın gibi doğal risklerin tehdidi altında olan bir yörede yer almaktadır. Örneğin Erzincan, tarihi boyunca çeşitli büyüklüklerde depremlere sahne olmuştur. Özellikle, 1939 ve 1992 yıllarında meydana gelen depremler, insanlar ve yapılar üzerinde önemli derecede can ve mal kayıplarına neden olmuştur. Yapılacak planlamaların böylesine riskli bir alanda olduğu göz ardı edilmemelidir.

İkinci grupta ise insan faaliyetleri sonucu meydana gelen çevresel sorunlardır. Bunlar, toprak, su, hava kirliliği, katı atıklardan ileri gelen kirlilikler, hassas yörede meydana gelen çevre sorunlarıdır. Erzincan'daki hava kirliliğinin en önemli kaynağı evsel 1sınma ve trafiktir. Bunu madencilik, küçük sanayi gibi faaliyetler izlemektedir. Yüzey suları (Karasu Nehri, Köroğlu Deresi) 2. Sınıf kaliteye sahiptir. $\mathrm{Bu}$ suların kirlenme nedenleri evsel atık sular, evsel katı atıklar, sanayi atıkları ve tarımsal faaliyetlerdir. Erzincan'da toprak kirliliğine neden olan başlıca etmen aşırı yapay gübre kullanımıdır. Bunu, aşırı tarım ilacı kullanımı, bilinçsiz sulama, plansız kentleşme, vahşi depolanan evsel katı atıklar ve sanayi atıklarının yarattığı kirlilikler izler. Öte yandan Ekşisu Sazlığı ve Girlevik Şelalesi insan faaliyetlerinin tehdidi altında olan Erzincan'nın en duyarlı iki alanıdır.

Günümüzdeki arazi kullanım biçimleri gözden geçirildiğinde yörede yeni bir planlamaya gereksinim olduğu anlaşılmaktadır. Önerilen planlama esas alınırsa, çevresel sorunların büyük bir bölümü denetlenip, Erzincan Ovas1 ve dolayının korunması da mümkündür. Örneğin, katı atıklar için öngörülen yer, uygun değildir. Yöredeki kirlilikler nedeniyle, estetik görüntünün bozulması, yüzey ve yeraltı sularının kirlenmesi, kuş sürülerine olan olumsuz etkiler, koku sorunu, haşerelerin artması kaçınılmaz gibi görünmektedir (Çevre ve Şehircilik Bakanlığı, 2012). Oysa Erzincan yöresinde deponi alanları için uygun olan geçirimsiz yerler vardır (Çizelge 4; Şekil 8). Ya da seçilen yerin, deponi alanı için gerekli tüm ölçütleri karşılayan bir alana dönüştürülmesi gerekir.

Ekşisu Sazlığı için alınması gereken önlemler şunlardır: Duyarlı alana deşarj edilen 
/boşaltılan her türlü atığın bertaraf edilmesi ve çevre mevzuatına uygun olarak yeniden düzenlenmesinin sağlanması, ayrıca bölgede erozyonla mücadele çalışmalarının sürdürülmesi gerekir.

Girlevik Şelalesi için alınması gereken önlemler şunlardır: Bu bölgedeki su rejimlerinin denetlenerek kullanım altına alınması ve bölgenin mevcut durumunu gözeterek, kalıcı yasal çerçevenin oluşturulması ve bölgeye dair bilinçli bir ÇED çalışmasının yapılması gerekmektedir.

Doğa kaynaklı risklerin etkilerini azaltmak için birleşik doğal risk haritalarının ayrıntılı olarak oluşturulması gerekir. Deprem, heyelan, sel ve taşkın ile çığ haritalarını ayrı ayrı oluşturup bunların örtmeler yöntemi ile birleştirilmesi ve buna bağlı olarak en güvenli yerlerin tercih edilmesi esastır.

Erzincan Ovası'nın yeniden planlamasında gözetilmesi gereken yeni hususlar ise Şekil 12'de sunulmuştur. $\mathrm{Bu}$ öneriler gözetilirse, Ova'nın çevresini izleyen bir demiryolu ring sistemi öncelikli bir konudur. Bu sistem hava kirliliğinin önüne geçilmesinde büyük katk1 sağlayacak ve halkın istediği şekilde istediği yere ulaşmasına olanak tanıyacaktır. Ayrıca, Firat nehrinin kenar kısımlarına setler yaparak, tarım ve yerleşim birimlerinin taşkın tehlikesi ortadan kaldırılabilir. Böylece koruma altına alınan alanlar, başka amaçlarla da kullanılabilir bir duruma gelmiş olacaktır. Ovanın kuzeydoğusu, güneybatısı ve batı bölümleri ise dinlenme amaçlı ve alabalık üreticiliği için uygun alanlardır.

\section{KATKI BELIRTME}

Yapılan çalışma, Cumhuriyet Üniversitesi Araştırma Fonu tarafindan M-551 kodu ile desteklenmiştir. $\mathrm{Bu}$ çerçevede, projemizi inceleyen, önerilerde bulunan ve onaylayan yetkililere de teşekkür ederiz. Ayrıca, makalemizi emek vererek ve ayrıntılı bir şekilde inceleyerek katkıda bulunan editörlere teşekkür borçluyuz.

\section{KAYNAKLAR}

Akpınar, Z., 2010. Erzincan havzasının tektonik gelişiminin Paleomanyetik yöntemlerle analizi. Cumhuriyet Üniversitesi Fen Bilimleri Enstitüsü, Doktora tezi, Sivas, 170 s.

Aktimur, T., Tekirli, M. E., Yurdakul, M. E., 1988. Erzincan ve çevresinin arazi kullanım potansiyeli. MTA Derleme Rapor no. 8381, Ankara, 326s.

Aktimur, T., Yurdakul, M. E., Sariaslan, M., Mutlu, G., Keçer, M., Yıldırım, T., Akkuş, İ., 1995. Geology of Erzincan regional petrology of Quaternary volcanic rocks. Symposium on the Black Sea Region Eds. Erler et al., General Directorate of MTA, Ankara, 82-90.

ANON, 1979. Classification of rocks and soils for engineering geological mapping. Part 1: Rock and soil materials. IAEG Bulletin, 19, 364-371.

Arpat, E., Şaroğlu, F., 1975. Türkiye'de bazı önemli genç tektonik olaylar. Türkiye Jeoloji Kurumu Bülteni, 18/1, 91-101.

Avcı, N., Kılıçdağı, R., Ayaz, M., 1997. Sivas kentinin çevre jeolojisi ve doğal kaynakları. MTA Orta Anadolu 1. Bölge Müdürlüğü, Sivas, 169s.

Barka, A., 1984. Erzincan Havzası'nın bazı neo-tektonik özellikleri. I. Ulusal Deprem Sempozyumu, Bildiriler kitab1, Erzurum, s. 223247.

Barka, A. A., Gülen, L., 1989. New constraints on the age and total offset of the North Anatolian Fault Zone: implifications for tectonics of the Eastern Mediterranean Region. METU Journal of Pure Applied Science, 21, 39-63.

Boz, D., 2015. Erzincan İli ve Dolayının Çevre Jeolojisi ve Geleceğe Yönelik Planlaması. TC Cumhuriyet Üniversitesi, Fen Bilimleri Enstitüsü, Yüksek lisans tezi (Yayımlanmamış), Sivas, $109 \mathrm{~s}$. 
Brown, L. F., Jr., Fisher, W. L. , Erxleben, A. W, McGowen, J. H., 1971. Resource capability units, their utility in land-and water-use management with examples from the Texas Coastal Zone: The University of Texas at Austin, Bureau of Economic Geology Geological Circular, 71-1, $22 \mathrm{p}$.

Cendero, A., 1974. Environmental geology of the Santander Bay area, Northern Spain. Environmental Geology, 1, 97-114.

Çevre ve Şehircilik Bakanlığı, 2012. Türkiye çevre sorunları ve öncelikleri envanteri değerlendirme raporu, Ankara, 196s.

Doornkamp, J. C., Brunsden, D., Cooke, R. U., Jones, David K. C., Griffiths, J. S., 1987. Environmental geology mapping: an international review. Geological Society Engineering Geology Special Publication, 4. s. 215-219. ISSN 0267-9914.

DSI, 1981. Erzincan Ovası hidrojeolojik etüt raporu, Devlet $\mathrm{Su}$ İşleri Genel Müdürlüğü (DSI), Jeoteknik Hizmetler ve Yeraltı Suları Dairesi Başkanlığı, Ankara, 124s.

DSİ, 2010. Firat nehri yan kolları su kalitesi. Orman ve $\mathrm{Su}$ İşleri Bakanlığı, Devlet Su İşleri Genel Müdürlüğü, 82. Şube Müdürlüğü, Erzincan.

Emre, Ö., Duman T. Y., Kondo, H., Olgun, Ş., Özalp, S., Elmac1, H., 2012. 1/250 000 ölçekli Türkiye Diri Fay Haritası Serisi, Erzincan (NJ 37-3) Paftas1, Seri no: 44, Maden Tetkik ve Arama Genel Müdürlüğü, Ankara.

Erzincan Valiliği, 2011. Erzincan İli Çevre Durum Raporu, Erzincan Çevre İl Müdürlüğü, Erzincan, 268s.

Faccini, F., Piccazzo, M. And Robbiano, A., 2008. Environmental geological maps of San Fruttuoso Bay (Portofino Park, Italy). Journal of Maps, 4/1, 431-443.

ISRM, 1981. Rock Characterization Testing and Monitoring. (Ed.), E. T. Brown, ISRM (International Society for Rock Mecanics) Suggested Methods. Pergaman Press, Oxford, England, 211s.
Keçer, M., 1985. Erzincan Ovası'nın ve yakın çevresinin jeomorfolojisi. İ.Ü Deniz Bilimleri ve Coğrafya Enstitüsü, Jeomorfoloji Anabilim Dalı, Yüksek lisans tezi, İstanbul.

Kılıçdağı, R., Sarıaslan, M., Ak, S., Şanver, S., Akbulut, I., Nisan, E., 1999. Kayseri kenti'nin çevre jeolojisi ve doğal kaynakları. MTA Derleme Rapor No: 10.322, Ankara, 125s.

Koçyiğit, A., 1991. Neotectonic structures and related landforms expressing the contractional and extensional strains along the North Anatolian Fault at the northwestern margin of the Erzincan basin, NE Turkey. Bulletin of İstanbul Technical University, 44, 455-473.

MTA, 2003. KAF boyu jeoloji haritası-(ErzincanTanyeri), 1/100.000 ölçekli ek, Maden Tetkik ve Arama Genel Müdürlüğü (MTA), Jeoloji Etütleri Dairesi, Ankara.

MTA, 2012a. 1/250. 000 Ölçekli Türkiye diri fay haritas1, Erzincan (NJ 37-3) paftas1, Seri no:44, Maden Tetkik ve Arama Genel Müdürlüğü (MTA), Jeoloji Etütleri Dairesi, Ankara.

MTA, 2012b. Erzincan ili maden ve enerji kaynakları, MTA Genel Müdürlüğü, Ankara, 5s.

Mulder, E.F.J.ve Hillen, R., 1990. Preparation and application of engineering and environmental geological maps in the Netherlands. Engineering Geology, 29, 279-290.

Özgül, N. 1981, Munzur dağlarının jeolojisi. MTA Derleme Rapor No, 6995, Ankara, 136s.

Shrestha, O. M., Koirala, A., Hanisch, J., Busch, K., Kerntke, M. ve Jager, S., 1999. A geoenvironmental map for sustainable development of the Kathmandu Valley, Nepal. GeoJournal, 49, 165-172.

Tudes, S. Ceryan, S. ve Bulut, F., 2012. Geoenvironmental evaluation for planning: an example from Gumushane City, close to the North Anatolia Fault Zone, NE Turkey. Bulletin of Engineering Geology and the Environment, 71 (4), 679-690.

Turner, A.K., Coffman, D.M., 1973. Geological for planning: a review of environmental geology, Quarterly of the Colorado School of Mines, $68 \mathrm{~s}$. 
Ulusay, R., 2010. Uygulamalı Jeoteknik Bilgiler. TMMOB Jeoloji Mühendisleri Odası yayınları, no. 38 , Ankara, $458 \mathrm{~s}$.

Vernes, D. J., 1978, Slope Movement Types and Processes. In Land slides: Analysis and Control. Edited by R. L. Schusterand R. J. Krizek. Transportation Research Board, National Academy of Science, Washington. Special Report 176, Chapter 2, 11-33.

Yılmaz, A. 1985. Yukarı Kelkit Çayı ile Munzur Dağları arasının temel jeoloji özellikleri ve yapısal evrimi: Türkiye Jeoloji Kurumu Bülteni, 28/2, 79-92.

Y1lmaz, A., Atmaca, E., 2006. Environmental geological assessment of a solid waste disposal site: A case study in Sivas, Turkey. Environmental Geology, 50, 67- 689.

Yılmaz, A. 2008. Çevre Jeolojisi. CÜ Mühendislik Fakültesi Yayını no: 107, Sivas, 379s.

Yılmaz, A. 2009. Çevre Jeotekniği. CÜ Mühendislik Fakültesi Yayını no: 116, Sivas, 276s. 